\title{
Does egg production represent adult female copepod growth? A call to account for body weight changes
}

\author{
A. G. Hirst ${ }^{1, *}$, A. D. McKinnon ${ }^{2}$ \\ ${ }^{1}$ Department of Biological Sciences, Heriot-Watt University, Edinburgh EH14 4AS, Scotland, UK \\ ${ }^{2}$ Australian Institute of Marine Science, PMB No. 3, Townsville MC, Queensland 4810, Australia
}

\begin{abstract}
An almost universal assumption in determining growth in copepods is that, over short periods, an individual adult female's net growth is equal to the amount of material expelled as eggs. This assumption relies upon adult body mass being in steady-state between the start and end of the same period. We explore different situations where this assumption is violated. Initially, concepts of how adult body weight and egg output are coupled over time are addressed. Using a refined concept of growth, we show that using typical $24 \mathrm{~h}$ incubation methods to measure egg output in sac spawners or broadcasters that produce clutches of eggs with a periodicity of $>1 \mathrm{~d}$ may give correct mean population growth rates, but erroneous individual rates (including maximum and minimum individual growth, and measurements of individual variability such as coefficient of variation). Measurements derived from laboratory and field studies are then used to explore errors associated with the steady-state assumption. Decoupling of egg production from assimilation, and non-steady-state body weight in large lipid-storing higher-latitude species are relatively well documented, yet growth estimates allowing for such changes have almost never been made. Errors are not limited only to such species, however, and changing adult body weights can occur in small temperate and tropical species too. Body weight can increase or decrease whether or not eggs are exuded over the same period. The errors that can arise if we assume that the output of eggs by females equals their net growth rate are large and variable; in our compilation they range from $-208 \%$ (i.e. egg output being $9.7 \%$ of body carbon weight per day, but adult carbon weight simultaneously declining by $13.7 \% \mathrm{~d}^{-1}$ ) to $+71 \%$ (i.e. egg output being $1.5 \%$ of body carbon weight per day, and adult carbon weight simultaneously increasing by $4.3 \% \mathrm{~d}^{-1}$ ). Using measurement of the natural variability in adult body weights, we determined that in order to be able to discriminate significant changes in body weight of 1 and $10 \%$ respectively, $>1000$ and $<100$ replicates are necessary, if applying typical sacrificial weighing methods. If we are to make accurate estimates of growth in adult copepods, then changes in body weight are of fundamental importance. We make initial recommendations for tackling these problems and reducing errors in the future
\end{abstract}

KEY WORDS: Copepod $\cdot$ Egg production $\cdot$ Body weight $\cdot$ Net growth

\section{INTRODUCTION}

Copepods are probably the most numerous metazoan sub-class on the planet (Mauchline 1998). They are the major metazoan grazers in the world's oceans,

*E-mail: a.hirst@hw.ac.uk and the principal trophic link between primary production and many planktivorous fish (e.g. Turner 1984). Copepods dominate the mesozooplankton usually comprising $80 \%$ of its biomass (Verity \& Smetacek 1996). Therefore, copepods are the focus of much attention in pelagic research.

Over the past few decades, considerable effort has been expended in determining species-specific growth 
in copepods, and their contribution to community secondary productivity. Production (P) by an individual over a time interval is defined as the rate of elaboration of biomass by that animal regardless of its fate, and may be described in the most simple form as:

$$
P=\left(B_{t}-B_{0}\right)+B_{\mathrm{r}}+B_{\mathrm{s}}
$$

where $B_{t}$ and $B_{0}$ are the body weight of the individual at Time $t$ and Time 0 respectively, $B_{\mathrm{r}}$ is the reproductive output over the same period, and $B_{\mathrm{s}}$ the biomass of somatic materials shed during this time (e.g. exuviae in copepods). In juvenile copepods (eggs to Copepodite Stage 5) growth is demonstrated as change in body weight $\left(B_{t}-B_{0}\right)$ and exuviae release $\left(B_{\mathrm{s}}\right)$. Once a copepod has reached the adult stage (Copepodite 6 ) there is no further moulting, and production can be expressed as output of reproductive material (eggs in females, spermatophores in males) as well as changes in body weight. Measurements of egg output (often termed egg production) are commonly made to assess growth of adult females, while body weight is seldom considered. Since adult copepods do not moult, and their integument is fairly rigid, negligible body weight increases have been assumed.

Adult females are the most commonly studied group when measuring copepod growth, presumably because of their relative importance, and ease of measurement in comparison to younger and smaller stages. 'Egg production' approaches have become central to attempts to quantify growth and production of marine copepods (Poulet et al. 1995, Runge \& Roff 2000). Although there are a variety of egg production methods, many are conceptually very similar. For broadcast spawning copepods the 'incubation approach' is most common. Animals are collected from the environment and incubated in natural or filtered seawater. Incubations are usually of $\sim 24 \mathrm{~h}$ duration because of the diurnal cycle in many physiological processes including egg-laying (Marshall \& Orr 1972, Marcus 1985, Runge 1985, Laabir et al. 1995). The average or individual daily weight-specific growth $\left(g_{\mathrm{f}}, \mathrm{d}^{-1}\right)$ is then expressed as:

$$
g_{\mathrm{f}}=\left(B_{\mathrm{e}} / W_{\mathrm{a}}\right) \times 24 / T
$$

where $T$ is the period of incubation (h), $W_{\mathrm{a}}$ the individual or mean adult female weight, and $B_{\mathrm{e}}$ the total weight of eggs produced per female over the period $T$ (e.g. Peterson et al. 1991).

For sac spawners, the methods used are slightly more diverse. The 'incubation approach' described above has been used (e.g. Paul et al. 1990, Bautista et al. 1994, Calbet et al. 1996, Saiz et al. 1997, Calbet \& Agustí 1999), usually with the incubation of those individuals found upon sorting to lack eggs. A second method, the 'egg-ratio method' is also used. This approach involves collection and enumeration of eggs and adults from the water column. Weight-specific growth is then derived from the ratio of egg to adult female abundance $(E / F)$, the hatch rate of the eggs $\left(H R, \mathrm{~d}^{-1}\right)$, and the mean weight of the female $\left(W_{\mathrm{a}}\right)$ and egg $\left(W_{\mathrm{e}}\right)$ (e.g. Nielsen \& Sabatini 1996).

$$
g_{\mathrm{f}}=(E / F) \times H R \times\left(W_{\mathrm{e}} / W_{\mathrm{a}}\right) .
$$

Alternatively growth may be derived in a similar fashion, but from the duration of egg development (D, days) (e.g. McKinnon \& Klumpp 1998):

$$
g_{\mathrm{f}}=(E / F \times \mathrm{D}) \times\left(W_{\mathrm{e}} / W_{\mathrm{a}}\right)
$$

Many studies have been published using these methods, and it has been suggested that egg production can be used as a standard protocol to map copepod production (Poulet et al. 1995). Both the 'incubation approach' and the 'egg-ratio method' have assumptions inherent in their use, yet one is fundamental and often ignored: if egg production equates to net growth of an adult female over a period of time, then the body weight of that female must be the same at the end of that same period as at the start (i.e. steady-state).

Rates of egg output have been used to measure growth of adult female copepods for many decades, in studies of tropical (Chisholm \& Roff 1990, Webber \& Roff 1995), temperate (Landry 1978, Peterson et al. 1991, Uye \& Shibuno 1992, Hay 1995, Calbet et al. 2000), through to sub-polar and polar regions (Hirche et al. 1991, Diel \& Tande 1992, Nielsen \& Hansen 1995). Investigators have suggested that: 'egg production thus represents the female production' (Hirche 1996, describing growth in Calanus finmarchicus); that the 'egg production rate represents the net production rate of adult females' (Liang \& Uye 1997): and have assumed that adult somatic production is negligible (McLaren \& Corkett 1981, Berggreen et al. 1988, Chisholm \& Roff 1990). The underlying assumption that adult weight must be steady-state (e.g. Scenario B in the following example) has very seldom been examined in detail. Many workers when examining lipidstoring large copepods such as Calanus spp., especially in high latitudes, appreciate that egg production may not equate to growth. Large Calanus species in seasonal environments may have body weights that increase or decrease, and egg production may be fuelled by lipid reserves and body protein (see Armstrong et al. 1991, Hirche \& Niehoff 1996, Calbet \& Irigoien 1997, Carlotti \& Hirche 1997). Stored reserves may also be metabolised during over-wintering phases, or in the development of ovaries and maturation (Gatten et al. 1980, Tande \& Hopkins 1981, Hirche \& Kattner 1993, Hagen \& Schnack-Schiel 1996). However, even in these environments attempts to calculate 


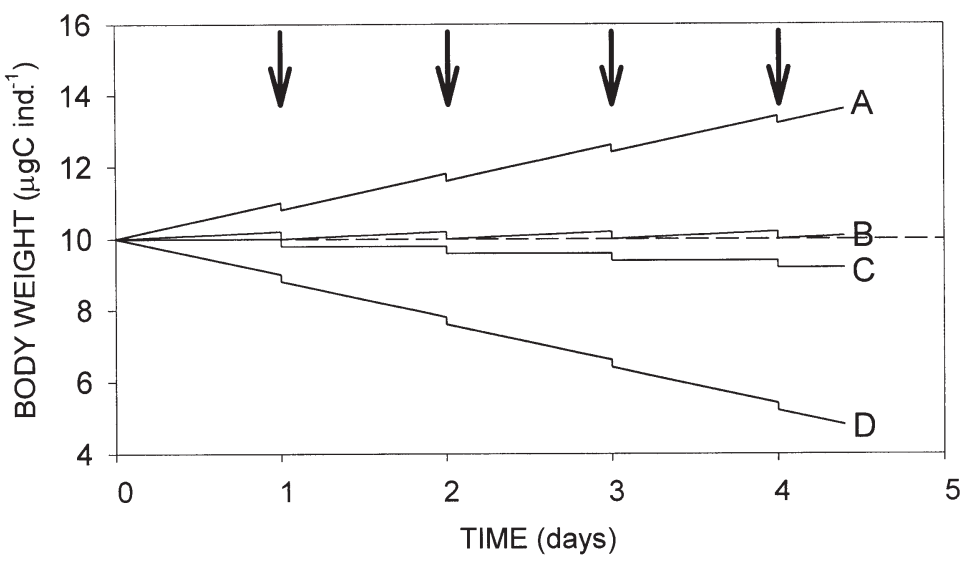

Fig. 1. Four scenarios for the body weight of individual adult copepods that exude an egg mass of $0.2 \mu \mathrm{gC}$ every $24 \mathrm{~h}$ (monitoring arrows). A: adult exudes eggs and continues to increase in weight; B: adult increases in weight but then exudes increase as eggs every $24 \mathrm{~h}$; C: adult weight declines simply as a function of egg output; D: adult weight declines as a function of egg output but with additional weight loss. Dashed line: constant body weight of $10 \mu \mathrm{gC}$ ind. ${ }^{-1}$ over time

growth allowing for body weight change as well as egg output are rare. Lipid reserves, as a percentage of total dry weight, are generally greatest for high-latitude species and lowest in low latitude species (Båmstedt 1986). This may explain why appreciation of variable adult body weight is mostly acknowledged in coldwater environments and apparently almost never in warmer waters. Of course, if one is only interested in measuring rates of egg release or recruitment, then whether fecundity actually equates to growth may not be of importance. When examining net growth or measurements dependent upon this term, changes in adult body weight are clearly fundamental.

We will begin by illustrating the assumption of steady-state adult body weight, with hypothetical adult copepods that shed eggs to the environment every $24 \mathrm{~h}$ (see Fig. 1). In Scenario A, body weight increases in addition to eggs being produced. In Scenario $\mathrm{B}$ the body weight increases over $24 \mathrm{~h}$ by an amount equivalent to the spawned egg mass. This mass is released upon spawning, hence body mass is steady-state between points separated by a $24 \mathrm{~h}$ period. In Scenario $\mathrm{C}$, the female uses body mass to produce eggs, and the adult weight declines every $24 \mathrm{~h}$ by an amount equal to the weight of eggs expelled. In Scenario D, the female loses weight and also produces eggs. In all cases, if the rate of egg output was assumed to represent growth this would give values of $0.2 \mu \mathrm{gC}$ ind. ${ }^{-1} \mathrm{~d}^{-1}$, whereas net growth in these examples are $1.0 \mu \mathrm{gC}$ ind. ${ }^{-1} \mathrm{~d}^{-1}$ (Scenario A), $0.2 \mu \mathrm{gC}$ ind..$^{-1} \mathrm{~d}^{-1}$ (Scenario B), $0.0 \mu \mathrm{gC}$ ind. ${ }^{-1} \mathrm{~d}^{-1}$ (Scenario C), and $-1.0 \mu \mathrm{gC}$ ind. ${ }^{-1} \mathrm{~d}^{-1}$ (Scenario D). Only in Scenario B does egg output represent the net growth of the female when measured over $24 \mathrm{~h}$ or multiples of this (e.g. $48 \mathrm{~h}, 72 \mathrm{~h}$, etc).

The aims of the present study were to: (1) Explore the crucial assumption of steady-state adult female weight and highlight different situations where this may be invalid; (2) determine the errors that may occur when egg output (production) alone is assumed to equal the net growth of adult females; (3) give initial suggestions on overcoming potential errors and quantifying the number of replicates necessary to measure adult weight changes of similar magnitude to typical egg output. We approached these aims using theoretical scenarios, previously published data and new measurements.

\section{MATERIALS AND METHODS}

Hypothetical populations. Many small temperate species have periods of very high egg output followed by days of zero or very low egg output, e.g. Centropages typicus (Carlotti et al. 1997, Razouls 1982), Temora stylifera (Razouls 1982) and Acartia spp., (Uye 1981). This pattern may relate to day-to-day variability in rates of feeding, digestion and assimilation of food into new tissue. These variations may drive the observed day-to-day differences in egg output, while body weight remains constant; although usually not stated by investigators when using egg production to describe net growth rates, they have effectively accepted such a mechanism. An alternative mechanism can be put forward, which if correct would lead to such assumptions being flawed. Rates of assimilation and production of new tissue could be relatively constant day-to-day, and instead egg output might be variable. In fact, for sac-spawners, and broadcasters which produce clutches of eggs, one would not expect rates of egg output over a $24 \mathrm{~h}$ incubation period necessarily to reflect the rate of net growth over the same period. Egg release might only occur over brief periods with significant periods between release. In sacspawners it is well documented that clutches of eggs are shed with an inter-spawn period (cycle duration, Hopcroft \& Roff 1996) of 1 to several days (Uye et al. 1982, Sabatini \& Kiørboe 1994, Hopcroft \& Roff 1996, Andersen \& Nielsen 1997, Ambler et al. 1999). Egg output is therefore limited by the egg hatch-time and the inter-clutch period. The inter-spawn period in many Calanus species can be from $24 \mathrm{~h}$ up to several weeks (Conover 1967, Marshall \& Orr 1972, Runge 1984, Peterson 1988, Hirche 1989, 1990, Tourangeau \& Runge 1991, Diel \& Tande 1992; also see Kosobokova 1994 and Hirche \& Niehoff 1996). Other broadcasters 
such as Neocalanus plumchrus and Sinocalanus tenellus (see descriptions in Mauchline 1998) exude clutches of eggs with great day-to-day variability.

The question as to whether the body of an animal stores mass until release as eggs, or whether eggs are instead released at the same rate as material assimilated into the body, may not seem to be of direct importance, but this is fundamental to the current methods used. Let us clarify this using several hypothetical situations whereby eggs are produced with varying inter-spawn periods, and the body is used to 'store' the egg mass until release. Current methods are designed so that the weight of eggs produced by a female copepod during an incubation period is attributed as growth exclusively over the incubation period. However, egg output is a mechanism of release and should not necessarily be regarded as a growth term in itself. The sources and sinks of material from within the body, and movement of material (carbon, nitrogen etc) from ingestion into and then between nutrient pools, structural mass, gonads and oocytes are important. Such compartments have been examined in some modelling studies (Sciandra et al. 1990, Carlotti \& Hirche 1997), but measurements of these, and movements of material between them, are difficult to make and almost unquantified at present. These compartment details are beyond the level at which we examine whole animal growth errors in this paper. We have chosen to examine these terms at the whole animal level because this is the level at which almost all practical studies on this topic to date have been made.

For an individual copepod the weight of an egg clutch must be accumulated between releases, and appear as changes in whole animal body weight. This might be manifested in 2 ways: as a constant clutch size with variable intervals between spawning (see Fig. 2), or as a constant rate of production with variable sizes of clutches (see Fig. 3). Body weight thus appears to change in a 'saw-tooth' pattern. We chose whole day units as spawning intervals because in nature they may often approximate to a number of whole day units; Oithona nana, O. simplex and Corycaeus amazonicus had inter-spawning intervals of $24 \mathrm{~h}$, and $O$. plumifera 48,72 or $96 \mathrm{~h}$ in tropical waters (see review by Hopcroft \& Roff 1996, cf. Peterson 1988). We have calculated growth rates of populations of such hypothetical individuals described in Figs 2 \& 3 in 2 ways: either accounting for body weight change and egg output (i.e. the true net growth), or by applying the 'Incubation Approach' equations. In both cases we have assumed that egg release is not synchronised among individuals, so for example, when the inter-spawn period is $2 \mathrm{~d}$ we assume $50 \%$ of the population release eggs over one day.
Incubated populations. Data were taken from published literature for adult females that had been incubated in containers and changes in body mass of individuals or populations derived. We only chose studies with adults, in order to avoid any weight changes resulting from an influx of different sized recruits. If egg mass production had been measured, then this data was also extracted. We did not discriminate the type of food supplied during the incubation period (e.g. natural food assemblage, mono-specific algal culture etc.) but we do discuss the implications of this. Incubation studies allow the examination of weight changes in populations where in nature it may not be possible to monitor such changes because of continued recruitment, size-selective mortality, and dispersion of copepods. However, such methods have the disadvantage that collected copepods may suffer handling stress, altered feeding behaviour, and changes in the turbulence of the environment, all of which could induce physiological changes.

Field populations. The field studies included here comprise those where changes in adult weight have been made on field populations through time. Again, we have limited our data selection to adults in which it was believed there is no further recruitment in order to avoid different weights of new females entering the breeding population. We excluded data where in an attempt to describe a single seasonal signal, samples collected over large geographical areas and over many different years were combined to produce a single seasonal signal (e.g. Hagen \& Schnack-Schiel 1996). The field-collection approach allows us an examination of natural populations free from some of the problems associated with incubations, but because smaller species in temperate and tropical regions often show continued recruitment, such data had to be excluded. The data we have obtained are thus primarily from coldwater regions.

Direct measurements of body weight change. Changes in body weight of adult females at different reproductive stages were measured in the freespawning copepod Scolecithrix danae, and in Calamoecia trifida, a freshwater calanoid that carries its eggs. Adult female $S$. danae were collected from the chlorophyll maximum ( $60 \mathrm{~m}$ ) off Myrmidon Reef, Australia $\left(18^{\circ} 14^{\prime} \mathrm{S}, 147^{\circ} 21^{\prime} \mathrm{E}\right)$ in November 1999 , and sorted according to the maturity of the ovary as: 'immature', 'medium' or 'ripe' (see Marshall \& Orr 1972, their Fig. 14). These samples were used to determine adult female weight changes that occur as females mature from pre-reproductive up to maturity. On 30 January 2000, plankton collections were made in the Ross River, Townsville, Australia (19 $\left.16^{\circ} \mathrm{S}, 146^{\circ} 47^{\prime} \mathrm{E}\right)$, from which we sorted $C$. trifida. Adults were separated into 3 groups, which we term: 'ripe', 'ovigerous' and 
'stripped'. Ripe females were identified as those adult females containing eggs within the ovaries. Ovigerous females were those carrying eggs in sacs, which were left attached for the subsequent weight measurements. Stripped females were those that were mature and ovigerous, but from which we removed the eggs sacs prior to weight determination. This experiment was designed to test whether we could directly observe the 'saw-tooth' pattern of body weight over a spawning cycle. Nitrogen content of individual $S$. danae females and groups of $5 \mathrm{C}$. trifida females were measured using an ANTEK chemiluminescent nitrogen analyser (Antek Instruments, Düsseldorf, Germany). A Beckman 880 NDIR analyser (Beckman Coulter, Fullerton, CA) was mounted in series for carbon analysis. These 2 case studies were designed to illustrate changes in body weight as a function of reproductive state/position on the spawning cycle, and did not include measurements of egg output rates.

Sample sizes needed to determine significant weight changes. Variance in body weight replicates of wild-caught adult females were compiled for many species in a variety of environments. The data set included large-bodied cold-water species to small tropical species. From data on each species we determined the sample sizes required for a 2-sample $t$-test to detect a significant difference with 1 and $10 \%$ changes in body weight, testing at the 0.05 level of significance, with a $90 \%$ chance of detecting a true difference between population means using methods described in Zar (1999). These percentage changes in body weight were chosen as they are similar in size to typical rates of egg production. Thus, if such changes occurred but were left unaccounted for, typical egg production terms would result in highly erroroneous calculations of the true net growth rate.

\section{RESULTS}

\section{Hypothetical populations}

Growth rates derived from the 'incubation approach' method (using egg output rates alone) and net growth (correctly including both egg output and body weight changes) for the examples presented in Figs $2 \& 3$ are detailed in Table 1. Daily rates in terms of individual maximum and minimum, coefficient of variation and mean values are given for each spawning interval of 1 , 2 or $5 \mathrm{~d}$. When the inter-spawn interval is $1 \mathrm{~d}$ the 'incubation approach' values are equivalent to the net growth values. This is because the inter-spawn period exactly matches the incubation period of $1 \mathrm{~d}$, and the body weight of any individual will be the same at the end of the period as at the start. However, when the inter-spawn period is greater than the incubation period, individual maximum and minimum values, and coefficient of variation derived from the 'incubation approach' are incorrect. The greater the inter-spawn period, the greater the divergence between the incubation results and the correct net growth values. In each scenario, body weight is steady-state at similar points in the reproductive cycle, and if this were not the case (e.g. Scenarios A, C and D in Fig. 1) then errors associated with 'egg production' approaches would be further exacerbated.

\section{Incubated populations}

Daily and total changes in body weight (dry, carbon, nitrogen, protein and lipid weights) for in vitro incubated populations are given in Tables 2 \& 3 respectively. Measured egg production rates are also

Table 1. Growth rates $\left(\mu \mathrm{gC}\right.$ ind. ${ }^{-1} \mathrm{~d}^{-1}$ ) of copepods in Figs $2 \& 3$ with inter-spawn periods of 1,2 and 5 d. Values derived applying the 'incubation approach' with $24 \mathrm{~h}$ incubations (i.e. egg output over this period used to derive growth) compared to those derived using body weight change and egg production (i.e. the true net growth rates). 'Incubation approach' values are in bold when they are incorrect compared to the true net growth rate. In our examples it has been assumed that when the inter-spawn period was $>1 \mathrm{~d}$ there was no inter-individual synchronicity in the day of spawning, and individuals continued to spawn with the same periodicity

\begin{tabular}{|c|c|c|c|c|c|c|}
\hline \multirow[t]{3}{*}{ Growth measure } & \multicolumn{6}{|c|}{ Inter-spawn period } \\
\hline & \multicolumn{3}{|c|}{ Incubation approach } & \multicolumn{3}{|c|}{ True net growth } \\
\hline & $1 \mathrm{~d}$ & $2 \mathrm{~d}$ & $5 \mathrm{~d}$ & $1 \mathrm{~d}$ & $2 \mathrm{~d}$ & $5 \mathrm{~d}$ \\
\hline Fig. 2 & Fig. 2a & Fig. 2b & Fig. 2c & Fig. 2a & Fig. 2b & Fig. 2c \\
\hline Max. individual growth & 0.50 & 0.50 & 0.50 & 0.50 & 0.25 & 0.10 \\
\hline Min. individual growth & 0.50 & 0.00 & 0.00 & 0.50 & 0.25 & 0.10 \\
\hline Coefficient of variation (\%) & 0 & 100 & 200 & 0 & 0 & 0 \\
\hline Mean growth & 0.50 & 0.25 & 0.10 & 0.50 & 0.25 & 0.10 \\
\hline Fig. 3 & Fig. 3a & Fig. 3b & Fig. 3c & Fig. 3a & Fig. 3b & Fig. 3c \\
\hline Max. individual growth & 0.50 & 1.00 & 2.50 & 0.50 & 0.50 & 0.50 \\
\hline Min. individual growth & 0.50 & 0.00 & 0.00 & 0.50 & 0.50 & 0.50 \\
\hline Coefficient of variation (\%) & 0 & 100 & 200 & 0 & 0 & 0 \\
\hline Mean growth & 0.50 & 0.50 & 0.50 & 0.50 & 0.50 & 0.50 \\
\hline
\end{tabular}




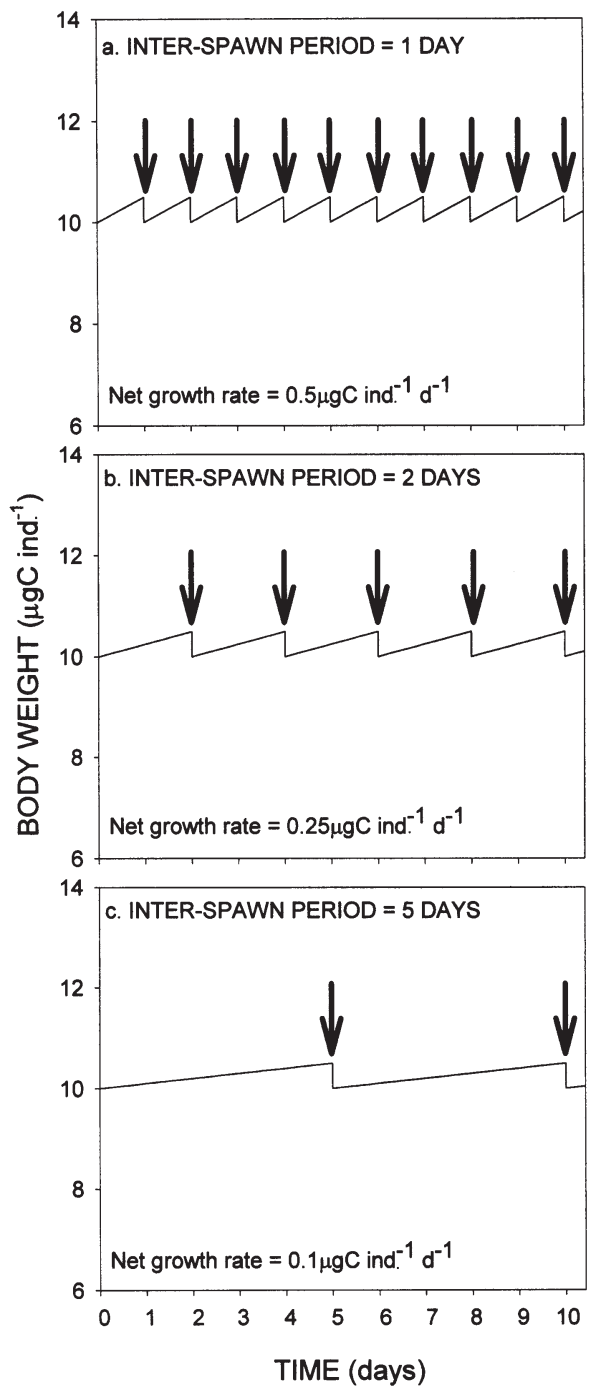

Fig. 2. Changes in the body weight of individual copepods that grow at different rates, and have different inter-spawn periods, but which exude the same weight of egg material when they spawn (arrows; $0.5 \mu \mathrm{gC}$ ind.$^{-1}$ spawning event ${ }^{-1}$ )

included in Table 2 together with the errors arising from considering egg output alone to represent growth (given as a percentage of the true net growth value). These errors range from -208.3 to $+71.4 \%$. The only studies where a natural assemblage of food has been supplied to a field-collected population and weight changes in adult females then examined as well as egg production are those of Durbin et al. (1992) and Koski \& Kuosa (1999). Unfortunately many incubation studies in which body weight changes have been included have not been completed using natural food sources. Investigators have often incubated wild-caught individuals in algal cultures or even filtered seawater; such weight changes in adults may therefore not be directly comparable to field situations.

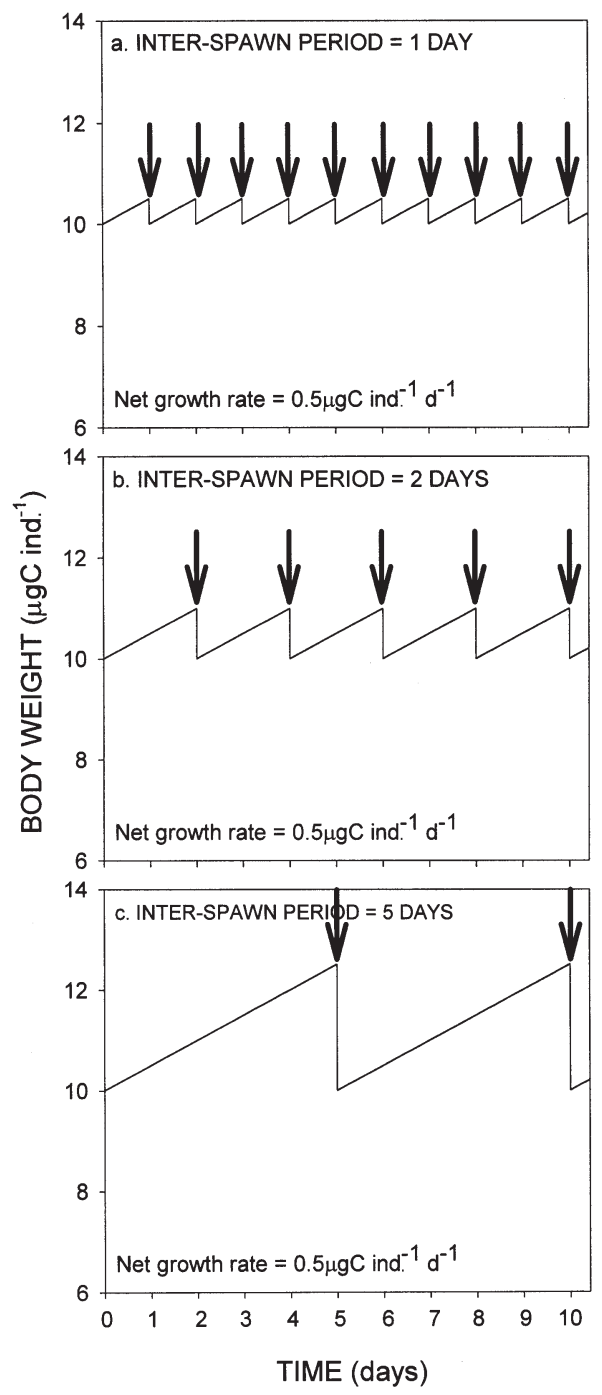

Fig. 3. Changes in body weight of individual copepods that grow at the same rate (i.e. $0.5 \mu \mathrm{gC}$ ind.$^{-1} \mathrm{~d}^{-1}$ ) but which have different lengths of time between each spawning event (arrows)

Durbin et al. (1992) found for Acartia hudsonica that body carbon increased by as much as $12.2 \% \mathrm{~d}^{-1}$, and decreased by as much as $7.0 \% \mathrm{~d}^{-1}$, with eggs being produced in both cases. The errors in these measurements that would arise if one had assumed that egg production alone equalled net growth (Table 2) range from $+28.3 \%$ (i.e. underestimation) to $-136.1 \%$ (i.e. overestimation). These are remarkably large considering that this species has small amounts of stored lipids in comparison to many larger species, and might be typically regarded as having very close coupling between egg production and net growth. Koski \& Kuosa (1999) incubated A. bifilosa in natural seawater for $48 \mathrm{~h}$ at a temperature equivalent to that below the thermocline (their Expts 3 and 4). Body carbon was found to 

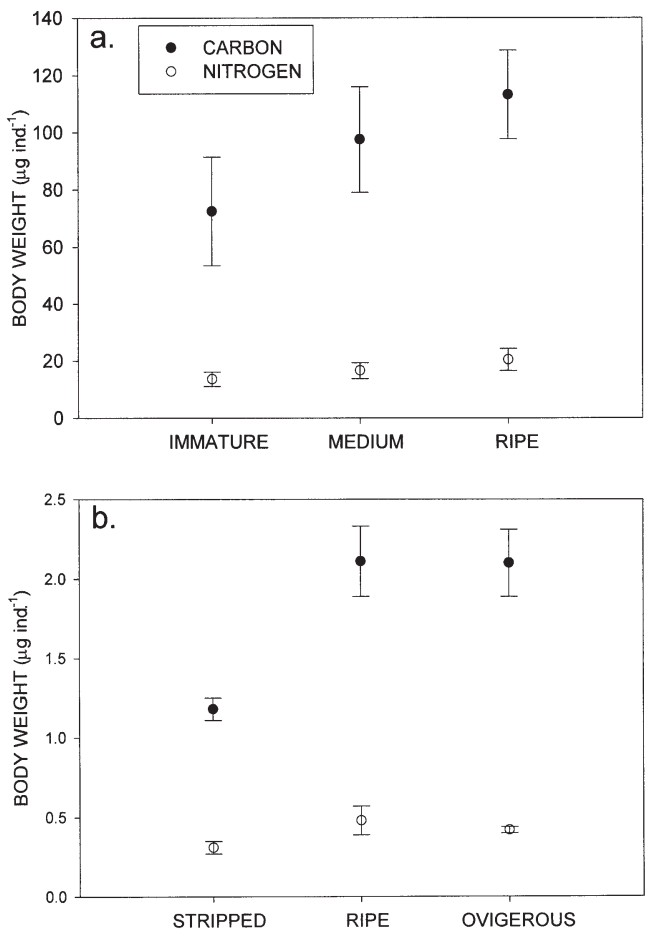

Fig. 4. Scolecithrix danae (a) and Calamoecia trifida (b). Mean $( \pm \mathrm{SD})$ body carbon $(\bullet)$ and nitrogen weight $(0)$ of adult female at different reproductive stages see 'Results' for details

decline by up to $13.7 \% \mathrm{~d}^{-1}$ and to increase by $7.1 \% \mathrm{~d}^{-1}$, whilst eggs were also produced. In this case, if body weight changes were not considered, the errors from net growth would be -208.3 and $+30.1 \%$ respectively.

Lipid weight losses of up to $85.3 \%$ in starved Calanus australis are possible (Table 3: data from Attwood \& Peterson 1989). Maximum reported increases in weights of adult females are for Acrocalanus gibber, with carbon and nitrogen increases of $>130 \%$ (McKinnon 1996). Acartia spp. demonstrate losses of $>20 \%$ in body carbon (Durbin et al. 1992, Koski \& Kuosa 1999), and up to $30 \%$ in dry weight (Durbin et al. 1992).

\section{Field populations}

Large increases and decreases in average daily female weight are observable in these natural populations (Table 2), suggesting that body weight changes are not limited to artificial incubation approaches, but occur in the natural environment. Unfortunately, because of the methodologies we have adopted to ensure that single populations are followed (with no significant recruitment to the adults over the period of body weight change), we have been limited to colder-water studies on larger animals. In some field cases we may have underestimated growth by up to $100 \%$, and in other cases it has been overestimated by up to $100 \%$. Those studies for which we have obtained body weight data do not include egg production, and so we have only been able to establish crude limits to the net growth errors.

Estimates of total body weight changes for field populations are relatively limited (Table 3 ). The study of Hopkins et al. (1984) showed increases of 146.1 and $191.5 \%$ in dry weight and carbon weight respectively in Calanus finmachicus in Balsfjorden, northern Norway. Losses as high as $45.3 \%$ of dry weight for Paralabidocera antarctica from a coastal sites in Antarctica have been reported (K. Swadling pers. comm.). Evanson et al. (2000) found dry weight losses of $71.5 \%$ in Neocalanus plumchrus in the Strait of Georgia, British Columbia, Canada, over a $45 \mathrm{~d}$ period.

\section{Direct measurement of body weight change}

Carbon and nitrogen weight varied with different reproductive states for the 2 chosen species, Scolecithrix danae and Calamoecia trifida (Fig. 4, Table 4). The carbon and nitrogen content of female $S$. danae differed according to reproductive maturity. Those with immature ovaries did not have significantly different amounts of body carbon or nitrogen than those with medium development (Student's $t$-test; $\mathrm{p}>0.05$ ), neither did the medium development group differ significantly from ripe individuals $(p>0.05)$. However, the ripe individuals did have significantly higher carbon and nitrogen weights than immature individuals ( $p=0.010$ for carbon, $\mathrm{p}=0.015$ for nitrogen). $C$. trifida differed in their body carbon and nitrogen weight according to their stage in the clutch cycle. Stripped $C$. trifida females contained significantly less carbon and nitrogen than those that were either ovigerous $(p<$ 0.001 for carbon, $p=0.001$ for nitrogen) or ripe ( $p<0.001$ for carbon, $\mathrm{p}=0.004$ for nitrogen), whereas ripe females were not significantly different from ovigerous females $(p>0.05)$. The ripe females might be considered as being near the top of the 'saw-tooth' pattern while the stripped individuals are near the bottom. The ovigerous females are also at the bottom; although they have an apparent weight similar to the ripe individuals, as their weight includes an external egg mass. Their actual body weight (without eggs) equals that of the stripped individuals.

\section{Sample sizes needed to determine significant weight changes}

The sample sizes necessary to assess 1 and 10\% changes in body weight (Zar 1999) are given in Table 5. Replication sizes seem practical for detecting $10 \%$ changes, often with $<100$ replicates necessary (i.e. 50 
Table 2. Measured daily increases and decreases in dry weight (DW), carbon (C), nitrogen (N), protein (Pro) and lipid (Lip) content of female copepods, together with measured rates of egg production (both sets of values determined as percentage of initial adult weight per day) for in vitro incubated populations and in situ field populations. All Copepods were Stage C6 except where indicated. \% Error: percentage error of net growth (allowing for both egg and body weight growth) that would arise by considering egg production (ep) alone (i.e. not allowing for body weight changes) to be net growth $(\mathrm{np})$, derived using equation $\{(\mathrm{np}-\mathrm{ep}) / \mathrm{np}\} \times 100$. Positive values indicate under-estimation, negative values over-estimation of net growth. Error derived from carbon units or from units in which measurements were made. -: no data

1 Changes in weight derived from their Table 2, copepods believed to be adult females (T. Ikeda pers. comm.); 2 Values taken from their Table I. 3 Values from their Table 5; only statistically significant changes given here (in the $2 \mathrm{~d}$ expts this was on 3 of 6 and 2 of 6 occasions for $\mathrm{C}$ and $\mathrm{N}$ respectively; in the 4 d expts this was on 3 of 8 and 1 of 8 occasions). 4 Changes in body weights and egg production rates from their Tables 1 \& 2 ; only statistically significant changes given here; egg production rate calculated as percentage of initial body weight over period and assuming egg weight of $0.041 \mu \mathrm{gC}$ (Kiørboe \& Sabatini 1995). 5 Increase in weight of those individuals kept in algaeenriched natural seawater compared to incubations in ambient seawater for $2 \mathrm{~d}$ over same period; value taken from their Table 1 ; egg production calculated as percentage body weight (measured at end of enriched incubation period) and assuming egg weight of $0.041 \mu \mathrm{gC} .6$ Values from their Table; only statistically significant changes given here. 7 Only significant change in October 1993 given here, where females after moult to adult were followed through time. 8 Weight changes from his Table 3; egg production rate given his text; error derived from assuming egg production of $5.56 \%$ body carbon $\mathrm{d}^{-1}$ (Table 1 ) over $77 \mathrm{~d}$ for female of $101 \mu \mathrm{gC}$ i.e. $432.4 \mu \mathrm{gC}$ produced in eggs compared with loss of $16 \mu \mathrm{gC}$ over the $77 \mathrm{~d}$ incubation period. 9 Changes estimated from their Table 3 using weights at Stn 1 as Time 0 values. $10 \mathrm{Egg}$ production rates determined from their Table 2 for Stn 1 (egg weights as in their Table 3). 11 Changes in body weight derived from their Table 5 by comparing mean weights of wild females collected on the 21 February (considered as Time 0 values) with weights after egg production experiment; duration of egg production taken from their Table 4 for each individual; females with large oocytes were selected for incubation, whereas wild females (with no apparent selection) were used as Time 0 to determine weight loss during incubation; mean egg and adult weight ( 0.37 and $299 \mu \mathrm{gC}$ respectively) used to estimate weight-specific egg production rates; growth error derived assuming that carbon weights declined over course of experiment because protein and lipid values decreased. 12 Weight changes derived from their Table 1; adult females were believed to be predominant stage (T. Ikeda pers. comm.). 13 Weight loss described as 'due only to metabolic losses as no eggs are produced during periods of extended starvation', hence zero egg production assumed here; lipid loss for each day predicted from their empirical equation: lipid content $(\mathrm{mg})=0.034 \mathrm{e}^{-0.208 \text { days }} .14$ Comparison for weight loss made between individuals fed Prorocentrum micans and Thalassiosira weissfloggi for $18 \mathrm{~h}$ and those starved for $18 \mathrm{~h}$ (no Time 0 values given). 15 Weight changes derived from daily means in their Table 1; wild controls used for Time 0 weights. 16 Values taken from their Table 8 (only total lipid values presented as dry weight values increased); starvation defined by authors as placing copepods in surface water passed through $35 \mu \mathrm{m}$ mesh net, assuming that the material passing through is unimportant to these large carnivores. 17 Weight changes taken from their text. $18 \mathrm{~K}$. Swadling pers. comm

\begin{tabular}{|c|c|c|c|c|c|c|c|c|c|}
\hline \multirow[t]{2}{*}{ Species } & \multirow{2}{*}{$\begin{array}{l}\text { Incubation conditions: } \\
\text { From, } \\
\text { to (at Time 0) }\end{array}$} & \multicolumn{5}{|c|}{$\begin{array}{c}\text { Change in Time } 0 \text { body wt } \\
\left(\% \text { wt } \mathrm{d}^{-1}\right)\end{array}$} & \multirow{2}{*}{$\begin{array}{c}\text { Egg production } \\
\text { rate }\left(\% \mathrm{wt} \mathrm{d}^{-1}\right) \\
\mathrm{C}\end{array}$} & \multirow{2}{*}{ Error } & \multirow[t]{2}{*}{ Source } \\
\hline & & DW & $\mathrm{C}$ & $\mathrm{N}$ & Pro & Lip & & & \\
\hline \multicolumn{10}{|c|}{ INCUBATED POPULATIONS } \\
\hline Acartia australis & $\begin{array}{l}\text { Field-collected copepods } \\
\text { (then ambient seawater for } 6 \mathrm{~h} \text { ), } \\
\text { ambient seawater for } 43 \mathrm{~h}\end{array}$ & - & - & - & -19.3 & - & - & 0 to -100 & $\begin{array}{l}\text { Ikeda \& } \\
\text { Skjoldal } \\
(1980)^{1}\end{array}$ \\
\hline Acartia bifilosa & $\begin{array}{l}\text { Ambient seawater for } 48 \mathrm{~h}, \\
\text { altered seawater for } 80 \mathrm{~h}\end{array}$ & - & 2.9 & - & - & - & 8.4 & 23.8 & \\
\hline Acartia bifilosa & $\begin{array}{l}\text { Ambient seawater for } 48 \mathrm{~h}, \\
\text { altered seawater for } 80 \mathrm{~h}\end{array}$ & - & 1.4 & - & - & - & 10.0 & 12.0 & \\
\hline Acartia bifilosa & $\begin{array}{l}\text { Ambient seawater for } 48 \mathrm{~h}, \\
\text { altered seawater for } 80 \mathrm{~h}\end{array}$ & - & 2.9 & - & - & - & 13.0 & 17.2 & \\
\hline Acartia bifilosa & $\begin{array}{l}\text { Ambient seawater for } 48 \mathrm{~h}, \\
\text { altered seawater for } 80 \mathrm{~h}\end{array}$ & - & 4.3 & - & - & - & 15.0 & 20.2 & \\
\hline Acartia bifilosa & $\begin{array}{l}\text { Ambient seawater for } 48 \mathrm{~h}, \\
\text { altered seawater for } 80 \mathrm{~h}\end{array}$ & - & 7.1 & - & - & - & 13.0 & 30.1 & \\
\hline Acartia bifilosa & $\begin{array}{l}\text { Ambient seawater for } 48 \mathrm{~h}, \\
\text { ambient seawater for } 80 \mathrm{~h}\end{array}$ & - & 2.1 & - & - & - & 4.7 & 29.4 & Koski \& \\
\hline Acartia bifilosa & $\begin{array}{l}\text { Ambient seawater for } 48 \mathrm{~h} \\
\text { ambient seawater for } 80 \mathrm{~h}\end{array}$ & - & 2.1 & - & - & - & 11.0 & 15.2 & $\begin{array}{l}\text { Kuosa } \\
(1999)^{2}\end{array}$ \\
\hline Acartia bifilosa & $\begin{array}{l}\text { Ambient seawater for } 48 \mathrm{~h}, \\
\text { ambient seawater for } 80 \mathrm{~h}\end{array}$ & - & -6.4 & - & - & - & 19.0 & -78.9 & \\
\hline Acartia bifilosa & $\begin{array}{l}\text { Ambient seawater for } 48 \mathrm{~h}, \\
\text { ambient seawater for } 80 \mathrm{~h}\end{array}$ & - & -6.4 & - & - & - & 22.0 & -60.0 & \\
\hline Acartia bifilosa & $\begin{array}{l}\text { Ambient seawater for } 48 \mathrm{~h}, \\
\text { ambient seawater for } 80 \mathrm{~h}\end{array}$ & - & 4.3 & - & - & - & 1.5 & 71.4 & \\
\hline Acartia bifilosa & $\begin{array}{l}\text { Ambient seawater for } 48 \mathrm{~h}, \\
\text { ambient seawater for } 48 \mathrm{~h}\end{array}$ & - & -13.7 & - & - & - & 9.7 & -208.3 & \\
\hline Acartia bifilosa & $\begin{array}{l}\text { Ambient seawater for } 48 \mathrm{~h}, \\
\text { ambient seawater for } 48 \mathrm{~h}\end{array}$ & - & -5.9 & - & - & - & 17.8 & -61.0 & \\
\hline
\end{tabular}


Table 2 (continued)

\begin{tabular}{|c|c|c|c|c|c|c|c|c|c|}
\hline \multirow[t]{2}{*}{ Species } & \multirow{2}{*}{$\begin{array}{l}\text { Incubation conditions: } \\
\text { From, } \\
\text { to (at Time 0) }\end{array}$} & \multicolumn{5}{|c|}{$\begin{array}{c}\text { Change in Time } 0 \text { body wt } \\
\left(\% \mathrm{wt} \mathrm{d}^{-1}\right)\end{array}$} & \multirow{2}{*}{$\begin{array}{c}\text { Egg production } \\
\text { rate }\left(\% \text { wt d }{ }^{-1}\right) \\
\text { C }\end{array}$} & \multirow{2}{*}{$\begin{array}{l}\% \\
\text { Error }\end{array}$} & \multirow[t]{2}{*}{ Source } \\
\hline & & DW & $\mathrm{C}$ & $\mathrm{N}$ & Pro & Lip & & & \\
\hline Acartia hudsonica & $\begin{array}{l}\text { Field-collected copepods, } \\
\text { algae-enriched seawater for } 2 \mathrm{~d}\end{array}$ & - & 7.0 & - & - & - & - & 0 to 100 & \multirow{7}{*}{$\begin{array}{l}\text { Durbin \& } \\
\text { Durbin } \\
(1992)^{3}\end{array}$} \\
\hline Acartia hudsonica & $\begin{array}{l}\text { Field-collected copepods, } \\
\text { algae-enriched seawater for } 2 \mathrm{~d}\end{array}$ & - & - & 13.7 & - & - & - & 0 to 100 & \\
\hline Acartia hudsonica & $\begin{array}{l}\text { Field-collected copepods, } \\
\text { algae-enriched seawater for } 2 \mathrm{~d}\end{array}$ & - & 18.6 & 21.3 & - & - & - & 0 to 100 & \\
\hline Acartia hudsonica & $\begin{array}{l}\text { Field-collected copepods, } \\
\text { algae-enriched seawater for } 2 \mathrm{~d}\end{array}$ & - & 11.3 & - & - & - & - & 0 to 100 & \\
\hline Acartia hudsonica & $\begin{array}{l}\text { Field-collected copepods, } \\
\text { algae cultures for } 4 \mathrm{~d}\end{array}$ & - & 26.7 & 12.3 & - & - & - & 0 to 100 & \\
\hline Acartia hudsonica & $\begin{array}{l}\text { Field-collected copepods, } \\
\text { algae cultures for } 4 \mathrm{~d}\end{array}$ & - & 12.8 & - & - & - & - & 0 to 100 & \\
\hline Acartia hudsonica & $\begin{array}{l}\text { Field-collected copepods, } \\
\text { algae cultures for } 4 \mathrm{~d}\end{array}$ & - & 9.5 & - & - & - & - & 0 to 100 & \\
\hline Acartia hudsonica & $\begin{array}{l}\text { Field-collected copepods, } \\
\text { algae-enriched seawater for } 2 \mathrm{~d}\end{array}$ & - & 5.4 & 6.4 & - & - & 19.2 & 22.1 & \multirow{21}{*}{$\begin{array}{l}\text { Durbin } \\
\text { et al. } \\
(1992)^{4}\end{array}$} \\
\hline Acartia hudsonica & $\begin{array}{l}\text { Field-collected copepods, } \\
\text { algae-enriched seawater for } 2 \mathrm{~d}\end{array}$ & - & 3.5 & - & - & - & 18.1 & 16.3 & \\
\hline Acartia hudsonica & $\begin{array}{l}\text { Field-collected copepods, } \\
\text { algae-enriched seawater for } 2 \mathrm{~d}\end{array}$ & - & -7.0 & -4.7 & - & - & 12.2 & -136.1 & \\
\hline Acartia hudsonica & $\begin{array}{l}\text { Field-collected copepods, } \\
\text { algae-enriched seawater for } 2 \mathrm{~d}\end{array}$ & - & 8.7 & 9.1 & - & - & 27.6 & 23.9 & \\
\hline Acartia hudsonica & $\begin{array}{l}\text { Field-collected copepod, } \\
\text { algae-enriched seawater for } 2 \mathrm{~d}\end{array}$ & 5.9 & 6.3 & 6.8 & - & - & 47.7 & 11.8 & \\
\hline Acartia hudsonica & $\begin{array}{l}\text { Field-collected copepod, } \\
\text { algae-enriched seawater for } 2 \mathrm{~d}\end{array}$ & 9.9 & - & 6.9 & - & - & 17.4 & 0 to 100 & \\
\hline Acartia hudsonica & $\begin{array}{l}\text { Field-collected copepod, } \\
\text { algae-enriched seawater for } 2 \mathrm{~d}\end{array}$ & - & 9.3 & 10.6 & - & - & 56.7 & 14.1 & \\
\hline Acartia hudsonica & $\begin{array}{l}\text { Field-collected copepods, } \\
\text { algae-enriched seawater for } 2 \mathrm{~d}\end{array}$ & - & 5.6 & - & - & - & 41.9 & 11.9 & \\
\hline Acartia hudsonica & $\begin{array}{l}\text { Field-collected copepods, } \\
\text { ambient seawater for } 2 \mathrm{~d}\end{array}$ & - & -6.1 & - & - & - & 11.1 & -121.8 & \\
\hline Acartia hudsonica & $\begin{array}{l}\text { Field-collected copepods, } \\
\text { ambient seawater for } 2 \mathrm{~d}\end{array}$ & - & 12.2 & 9.1 & - & - & 31.0 & 28.3 & \\
\hline Acartia hudsonica & $\begin{array}{l}\text { Field-collected copepods, } \\
\text { ambient seawater for } 2 \mathrm{~d}\end{array}$ & 6.0 & 7.4 & 7.1 & - & - & 46.6 & 13.8 & \\
\hline Acartia hudsonica & $\begin{array}{l}\text { Field-collected copepods, } \\
\text { ambient seawater for } 2 \mathrm{~d}\end{array}$ & 8.4 & - & 9.3 & - & - & 37.8 & 15.8 & \\
\hline Acartia hudsonica & $\begin{array}{l}\text { Field-collected copepods, } \\
\text { ambient seawater for } 2 \mathrm{~d}\end{array}$ & - & 4.9 & 7.9 & - & - & 51.4 & 8.7 & \\
\hline Acartia tonsa & $\begin{array}{l}\text { Algae-enriched seawater for } 1 \mathrm{~d} \\
\text { algae-enriched seawater for } 1 \mathrm{~d}\end{array}$ & 5.9 & - & - & - & - & 35.6 & 0 to 100 & \\
\hline Acartia tonsa & $\begin{array}{l}\text { Field-collected copepods, } \\
\text { algal culture incubation for } 1 \mathrm{~d}\end{array}$ & - & 27.4 & 24.8 & - & - & - & 0 to 100 & \\
\hline Acartia tonsa & $\begin{array}{l}\text { Field-collected copepods, } \\
\text { algal culture incubation for } 1 \mathrm{~d}\end{array}$ & 20.0 & 13.2 & 12.6 & - & - & - & 0 to 100 & \\
\hline Acartia tonsa & $\begin{array}{l}\text { Field-collected copepods, } \\
\text { algal culture incubation for } 1 \mathrm{~d}\end{array}$ & - & 24.8 & 22.8 & - & - & - & 0 to 100 & \\
\hline Acartia tonsa & $\begin{array}{l}\text { Field-collected copepods, } \\
\text { algal culture incubation for } 1 \mathrm{~d}\end{array}$ & 24.6 & 19.1 & 16.0 & - & - & - & 0 to 100 & \\
\hline Acartia tonsa & $\begin{array}{l}\text { Field-collected copepods, } \\
\text { algal culture incubation for } 1 \mathrm{~d}\end{array}$ & 16.2 & 9.7 & - & - & - & - & 0 to 100 & \\
\hline Acartia tonsa & $\begin{array}{l}\text { Field-collected copepods, } \\
\text { algal culture incubation for } 1 \mathrm{~d}\end{array}$ & 17.2 & 16.9 & - & - & - & - & 0 to 100 & \\
\hline Acartia tonsa & $\begin{array}{l}\text { Field-collected copepods, } \\
\text { algal culture incubation for } 1 \mathrm{~d}\end{array}$ & - & 10.7 & - & - & - & - & 0 to 100 & \\
\hline
\end{tabular}


Table 2 (continued)

\begin{tabular}{|c|c|c|c|c|c|c|c|c|c|}
\hline \multirow[t]{2}{*}{ Species } & \multirow{2}{*}{$\begin{array}{l}\text { Incubation conditions: } \\
\text { From, } \\
\text { to (at Time 0) }\end{array}$} & \multicolumn{5}{|c|}{$\begin{array}{c}\text { Change in Time } 0 \text { body wt } \\
\left(\% \text { wt } \mathrm{d}^{-1}\right)\end{array}$} & \multirow{2}{*}{$\begin{array}{l}\text { Egg production } \\
\text { rate }\left(\% \text { wt d }{ }^{-1}\right) \\
\text { C }\end{array}$} & \multirow{2}{*}{ Error } & \multirow[t]{2}{*}{ Source } \\
\hline & & DW & $\mathrm{C}$ & $\mathrm{N}$ & Pro & Lip & & & \\
\hline Acartia tonsa & $\begin{array}{l}\text { Field-collected copepods, } \\
\text { algal culture incubation for } 1 \mathrm{~d}\end{array}$ & 18.8 & 16.0 & 23.0 & - & - & - & 0 to 100 & \multirow{8}{*}{$\begin{array}{l}\text { Thompson } \\
\text { et al. } \\
(1994)^{6}\end{array}$} \\
\hline Acartia tonsa & $\begin{array}{l}\text { Field-collected copepods, } \\
\text { algal culture incubation for } 1 \mathrm{~d}\end{array}$ & 24.2 & 15.6 & 11.0 & - & - & - & 0 to 100 & \\
\hline Acartia tonsa & $\begin{array}{l}\text { Field-collected copepods, } \\
\text { algal culture incubation for } 1 \mathrm{~d}\end{array}$ & 23.8 & 48.6 & 37.4 & - & - & - & 0 to 100 & \\
\hline Acartia tonsa & $\begin{array}{l}\text { Field-collected copepods, } \\
\text { algal culture incubation for } 1 \mathrm{~d}\end{array}$ & 41.6 & 53.7 & 29.7 & - & - & - & 0 to 100 & \\
\hline Acartia tonsa & $\begin{array}{l}\text { Field-collected copepods, } \\
\text { algal culture incubation for } 1 \mathrm{~d}\end{array}$ & 44.4 & 61.1 & 37.9 & - & - & - & 0 to 100 & \\
\hline Acartia tonsa & $\begin{array}{l}\text { Field-collected copepods, } \\
\text { algal culture incubation for } 1 \mathrm{~d}\end{array}$ & - & 48.7 & 30.1 & - & - & - & 0 to 100 & \\
\hline Acartia tonsa & $\begin{array}{l}\text { Field-collected copepods, } \\
\text { algal culture incubation for } 1 \mathrm{~d}\end{array}$ & 39.3 & 31.3 & 22.4 & - & - & - & 0 to 100 & \\
\hline Acartia tonsa & $\begin{array}{l}\text { Field-collected copepods, } \\
\text { algal culture incubation for } 1 \mathrm{~d}\end{array}$ & 20.0 & 21.0 & - & - & - & - & 0 to 100 & \\
\hline Acrocalanus gibber & $\begin{array}{l}37 \mu \mathrm{m} \text { screened ambient seawater, } \\
37 \mu \mathrm{m} \text { screened amb. seaw. for } 5 \mathrm{~d}\end{array}$ & - & $\begin{array}{l}26.2 \\
20.1\end{array}$ & $\begin{array}{l}27.2 \\
18.5\end{array}$ & - & - & - & $\begin{array}{l}0 \text { to } 100 \\
0 \text { to } 100\end{array}$ & $\begin{array}{l}\text { McKinnon } \\
(1996)^{7}\end{array}$ \\
\hline $\begin{array}{l}\text { Calanus } \\
\text { finmarchicus }\end{array}$ & $\begin{array}{l}\text { Field-collected copepods, } \\
\text { algae }\left(>400 \mu \mathrm{gC} \mathrm{l}^{-1}\right) \text { for } 77 \mathrm{~d}\end{array}$ & -0.005 & 0.2 & -0.05 & - & - & 5.6 & -3.8 & $\begin{array}{l}\text { Hirche } \\
(1990)^{8}\end{array}$ \\
\hline Calanus glacialis & $\begin{array}{l}\text { Field-collected copepods, } \\
\quad \text { algae (above } 300 \mu \mathrm{gC} \mathrm{l}^{-1} \text { ) for } 77 \mathrm{~d}^{9}\end{array}$ & 0.2 & 0.1 & 0.6 & - & -0.9 & $2.5^{10}$ & 3.9 & \multirow{3}{*}{$\begin{array}{l}\text { Hirche \& } \\
\text { Kattner } \\
(1993)\end{array}$} \\
\hline Calanus glacialis & $\begin{array}{l}\text { Field-collected copepods, } \\
\text { algae (above } 300 \mu \mathrm{gC} \mathrm{l}^{-1} \text { ) for } 45 \mathrm{~d} \\
\text { followed by starvation for } 26 \mathrm{~d}^{9}\end{array}$ & -0.3 & -0.5 & -0.03 & - & - & - & 0 to -100 & \\
\hline Calanus glacialis & $\begin{array}{l}\text { Field-collected copepods, } \\
\text { starved for } 45 \mathrm{~d} \text { followed by } \\
\text { algae (above } 300 \mu \mathrm{\mu C} \mathrm{l}^{-1} \text { ) for } 26 \mathrm{~d}^{9}\end{array}$ & -0.2 & -0.4 & -0.1 & - & - & - & 0 to -100 & \\
\hline Calanus propinquus & $\begin{array}{l}\text { Field-collected copepods, } \\
\quad \text { algae (above } 300 \mu \mathrm{gC} \mathrm{l}^{-1} \text { ) for } 10 \mathrm{~d}\end{array}$ & - & - & - & -2.2 & -7.4 & 4.1 & 0 to -100 & \multirow{7}{*}{$\begin{array}{l}\text { Kosobo- } \\
\text { kova } \\
(1994)^{11}\end{array}$} \\
\hline Calanus propinquus & $\begin{array}{l}\text { Field-collected copepods, } \\
\quad \text { algae (above } 300 \mathrm{\mu gC}^{-1} \text { ) for } 13 \mathrm{~d}\end{array}$ & - & - & - & -2.3 & -6.0 & 1.9 & 0 to -100 & \\
\hline Calanus propinquus & $\begin{array}{l}\text { Field-collected copepods, } \\
\quad \text { algae (above } 300 \mathrm{\mu gC}^{-1} \text { ) for } 13 \mathrm{~d}\end{array}$ & - & - & - & -1.0 & -6.3 & 1.2 & 0 to -100 & \\
\hline Calanus propinquus & $\begin{array}{l}\text { Field-collected copepods, } \\
\quad \text { algae (above } 300 \mathrm{\mu gC}^{-1} \text { ) for } 46 \mathrm{~d}\end{array}$ & - & - & - & -0.8 & -1.0 & 0.6 & 0 to -100 & \\
\hline Calanus propinquus & $\begin{array}{l}\text { Field-collected copepods, } \\
\quad \text { algae (above } 300 \mathrm{\mu gC}^{-1} \text { ) for } 56 \mathrm{~d}\end{array}$ & - & - & - & -0.9 & -0.7 & 1.2 & 0 to -100 & \\
\hline Calanus propinquus & $\begin{array}{l}\text { Field-collected copepods, } \\
\quad \text { algae (above } 300 \mathrm{\mu gC} \mathrm{l}^{-1} \text { ) for } 56 \mathrm{~d}\end{array}$ & - & - & - & -1.1 & -1.1 & 0.5 & 0 to -100 & \\
\hline Paracalanus parvus & $\begin{array}{l}\text { Field-collected copepods, } \\
\text { algae for } 3 \mathrm{~d}\end{array}$ & 7.2 & - & - & - & - & - & 0 to 100 & \\
\hline Starved & & & & & & & & & \\
\hline Acartia bifilosa & $\begin{array}{l}\text { Ambient seawater for } 48 \mathrm{~h}, \\
\text { starved for } 80 \mathrm{~h}\end{array}$ & - & -8.6 & - & - & - & 3.6 & -140.5 & $\begin{array}{l}\text { Koski \& } \\
\text { Kuosa }(1999)^{2}\end{array}$ \\
\hline Calanus australis & $\begin{array}{l}4 \mathrm{~d} \text { fed Thalassiosira weissflogii } \\
\text { ad libitum, starved for } 1 \mathrm{~d}\end{array}$ & - & - & - & - & -17.6 & 0.0 & -100 & \multirow{5}{*}{$\begin{array}{l}\text { Attwood \& } \\
\text { Peterson } \\
(1989)^{13}\end{array}$} \\
\hline Calanus australis & $\begin{array}{l}4 \mathrm{~d} \text { fed Thalassiosira weissflogii } \\
\text { ad libitum, starved for } 2 \mathrm{~d}\end{array}$ & - & - & - & - & -17.7 & 0.0 & -100 & \\
\hline Calanus australis & $\begin{array}{l}4 \mathrm{~d} \text { fed Thalassiosira weissflogii } \\
\text { ad libitum, starved for } 3 \mathrm{~d}\end{array}$ & - & - & - & - & -15.7 & 0.0 & -100 & \\
\hline Calanus australis & $\begin{array}{l}4 \mathrm{~d} \text { fed Thalassiosira weissflogii } \\
\text { ad libitum, starved for } 4 \mathrm{~d}\end{array}$ & - & - & - & - & -14.0 & 0.0 & -100 & \\
\hline Calanus australis & $\begin{array}{l}4 \mathrm{~d} \text { fed Thalassiosira weissflogii } \\
\text { ad libitum, starved for } 5 \mathrm{~d}\end{array}$ & - & - & - & - & -12.9 & 0.0 & -100 & \\
\hline
\end{tabular}


Table 2 (continued)

\begin{tabular}{|c|c|c|c|c|c|c|c|c|c|}
\hline \multirow[t]{2}{*}{ Species } & \multirow{2}{*}{$\begin{array}{l}\text { Incubation conditions: } \\
\text { From, } \\
\text { to (at Time 0) }\end{array}$} & \multicolumn{5}{|c|}{$\begin{array}{l}\text { Change in Time } 0 \text { body wt } \\
\left(\% \text { wt } \mathrm{d}^{-1}\right)\end{array}$} & \multirow{2}{*}{$\begin{array}{l}\text { Egg production } \\
\text { rate }\left(\% \text { wt d }{ }^{-1}\right) \\
\text { C }\end{array}$} & \multirow{2}{*}{$\begin{array}{c}\% \\
\text { Error }\end{array}$} & \multirow[t]{2}{*}{ Source } \\
\hline & & DW & $\mathrm{C}$ & $\mathrm{N}$ & Pro & Lip & & & \\
\hline Calanus australis & $\begin{array}{l}4 \mathrm{~d} \text { fed Thalassiosira weissflogii } \\
\text { ad libitum, starved for } 6 \mathrm{~d}\end{array}$ & - & - & - & - & -11.8 & 0.0 & -100 & \multirow{4}{*}{$\begin{array}{l}\text { Attwood \& } \\
\text { Peterson } \\
(1989)^{13}\end{array}$} \\
\hline Calanus australis & $\begin{array}{l}4 \mathrm{~d} \text { fed Thalassiosira weissflogii } \\
\text { ad libitum, starved for } 7 \mathrm{~d}\end{array}$ & - & - & - & - & -10.9 & 0.0 & -100 & \\
\hline Calanus australis & $\begin{array}{l}4 \mathrm{~d} \text { fed Thalassiosira weissflogii } \\
\text { ad libitum, starved for } 8 \mathrm{~d}\end{array}$ & - & - & - & - & -10.3 & 0.0 & -100 & \\
\hline Calanus australis & $\begin{array}{l}4 \mathrm{~d} \text { fed Thalassiosira weissflogii } \\
\text { ad libitum, starved for } 9 \mathrm{~d}\end{array}$ & - & - & - & - & -9.5 & 0.0 & -100 & \\
\hline Calanus glacialis & ? starved for $77 \mathrm{~d}^{9}$ & -0.7 & -0.9 & -0.7 & -1.1 & - & $0.4^{10}$ & -149.1 & $\begin{array}{l}\text { Hirche \& } \\
\text { Kattner (1993) }\end{array}$ \\
\hline $\begin{array}{l}\text { Calanus helgo- } \\
\text { landicus }\end{array}$ & ? starved for $1 \mathrm{~d}$ & - & - & -7.6 & - & - & - & & $\begin{array}{l}\text { Corner et } \\
\text { al. (1976) }\end{array}$ \\
\hline $\begin{array}{l}\text { Calanus helgo- } \\
\text { landicus (C5 \& C6) }\end{array}$ & $\begin{array}{l}\text { Field-collected copepods, } \\
\text { starved for } 18 \mathrm{~h}\end{array}$ & - & - & -10.5 & - & - & - & 0 to -100 & $\begin{array}{l}\text { Hays et } \\
\text { al. }(1997)^{\mathbf{1 4}}\end{array}$ \\
\hline Chiridius armatus & $\begin{array}{l}\text { Field-collected copepods, } \\
\text { starved for } 1 \mathrm{~d}\end{array}$ & -2.9 & - & - & - & - & - & 0 to -100 & \multirow{4}{*}{$\begin{array}{l}\text { Alvarez \& } \\
\text { Matthews } \\
(1975)^{15}\end{array}$} \\
\hline Chiridius armatus & $\begin{array}{l}\text { Field-collected copepods, } \\
\text { starved for } 2 \mathrm{~d}\end{array}$ & -3.2 & - & - & - & - & - & 0 to -100 & \\
\hline Chiridius armatus & $\begin{array}{l}\text { Field-collected copepods, } \\
\text { starved for } 3 \mathrm{~d}\end{array}$ & -2.8 & - & - & - & - & - & 0 to -100 & \\
\hline Chiridius armatus & $\begin{array}{l}\text { Field-collected copepods, } \\
\text { starved for } 4 \mathrm{~d}\end{array}$ & -2.3 & - & - & - & - & - & 0 to -100 & \\
\hline Chiridius armatus & Field-collected copepods, & & & & & & & & \\
\hline Gaussia princeps & $\begin{array}{l}\text { Field-collected copepods, } \\
\text { starved for } 80 \mathrm{~h}\end{array}$ & - & - & - & - & -2.3 & - & 0 to -100 & \multirow[b]{2}{*}{$\begin{array}{l}\text { Lee et al. } \\
(1971)^{16}\end{array}$} \\
\hline Gaussia princeps & $\begin{array}{l}\text { Field-collected copepods, } \\
\text { starved for } 120 \mathrm{~h} \\
\text { starved for } 5 \mathrm{~d}\end{array}$ & -2.2 & - & $\begin{array}{l}- \\
-\end{array}$ & - & $\begin{array}{c}-1.5 \\
-\end{array}$ & - & $\begin{array}{l}0 \text { to }-100 \\
0 \text { to }-100\end{array}$ & \\
\hline Paracalanus parvus & $\begin{array}{l}\text { Field-collected copepods, } \\
\text { starved for } 3 \mathrm{~d}\end{array}$ & -2.8 & - & - & - & - & - & 0 to -100 & $\begin{array}{l}\text { Ikeda } \\
(1977)^{12}\end{array}$ \\
\hline FIELD POPULATIOI & $\begin{array}{l}\text { NS } \\
\text { Sampling area; time }\end{array}$ & & & & & & & & \\
\hline $\begin{array}{l}\text { Calanus } \\
\text { finmarchicus }\end{array}$ & $\begin{array}{l}\text { Balsfjorden, Northern Norway } \\
\text { January-April }\end{array}$ & -0.4 & -0.3 & 1.0 & - & - & - & 0 to -100 & \multirow{4}{*}{$\begin{array}{l}\text { Hopkins } \\
\text { et al. } \\
(1984)^{17}\end{array}$} \\
\hline $\begin{array}{l}\text { Calanus } \\
\text { finmarchicus }\end{array}$ & $\begin{array}{l}\text { Balsfjorden, Northern Norway } \\
\text { April-September }\end{array}$ & 1.0 & 1.3 & - & - & - & - & 0 to 100 & \\
\hline Metridia longa & $\begin{array}{l}\text { Balsfjorden, Northern Norway } \\
\text { October-March }\end{array}$ & -0.2 & - & - & - & - & - & 0 to -100 & \\
\hline Metridia longa & $\begin{array}{l}\text { Balsfjorden, Northern Norway } \\
\text { October-April }\end{array}$ & - & -0.2 & - & - & - & - & 0 to -100 & \\
\hline $\begin{array}{l}\text { Neocalanus } \\
\text { plumchrus }\end{array}$ & $\begin{array}{l}\text { Strait of Georgia, British Columbia } \\
21 \text { Jan } 97-10 \text { Feb } 97\end{array}$ & -3.0 & - & - & - & -3.2 & - & 0 to -100 & $\begin{array}{l}\text { Evanson et } \\
\text { al. }(2000)\end{array}$ \\
\hline \multirow{4}{*}{$\begin{array}{l}\text { Paralabidocera } \\
\text { antarctica }\end{array}$} & 10 Feb 97 - 6 Mar 97 & -1.1 & - & - & - & -0.5 & - & 0 to -100 & $\begin{array}{l}\text { M. Evanson } \\
\text { pers. comm. }\end{array}$ \\
\hline & $\begin{array}{l}\text { Coastal site, Antarctica } \\
15 \text { Dec } 93-22 \text { Dec } 93 \\
29 \text { Dec } 93-12 \text { Jan } 94\end{array}$ & $\begin{array}{r}2.4 \\
-2.4\end{array}$ & - & - & - & - & - & $\begin{array}{l}0 \text { to } 100 \\
0 \text { to }-100\end{array}$ & \multirow{3}{*}{$\begin{array}{l}\text { K. Swad- } \\
\text { ling pers. } \\
\text { comm. }{ }^{\mathbf{1 8}}\end{array}$} \\
\hline & $\begin{array}{l}\text { Coastal site, Antarctica } \\
15 \text { Dec } 94-17 \text { Dec } 94 \\
21 \text { Dec } 94-28 \text { Dec } 94\end{array}$ & $\begin{array}{c}12.0 \\
-5.2\end{array}$ & - & - & - & - & - & $\begin{array}{l}0 \text { to } 100 \\
0 \text { to }-100\end{array}$ & \\
\hline & $\begin{array}{l}\text { Ace Lake, Antarctica } \\
23 \text { Nov } 94-10 \text { Dec } 94 \\
23 \text { Dec } 94-13 \text { Jan } 95\end{array}$ & $\begin{array}{r}0.6 \\
-0.8\end{array}$ & $\begin{array}{l}- \\
-\end{array}$ & $\begin{array}{l}- \\
-\end{array}$ & - & $\begin{array}{l}- \\
-\end{array}$ & - & $\begin{array}{c}0 \text { to } 100 \\
0 \text { to }-100\end{array}$ & \\
\hline
\end{tabular}


Table 3. Measured total changes in weights (dry weight, DW; carbon, $\mathrm{C}$; nitrogen, $\mathrm{N}_{i}$ protein, Pro; and lipid, Lip) of female copepods. Changes are total percentage change from initial weight, where negative values indicate loss and positive values gain. All copepods were Stage C6 except where indicated

1 Changes in weight derived from their Table 2, copepods believed to be adult females (T. Ikeda, pers. comm.); 2 Values taken from their Table 1. 3 Only significant maximum increases and decreases in DW, C and $\mathrm{N}$ given here, data from their Table 2. 4 Data from their Table 1, only maximum decrease given here. 5 Values taken from their Table 5, only significant maximum changes given here. 6 Data taken from their Table 1, initial weights taken as 'ambient' incubation individuals from the same table. 7 Values from their Table 2, only statistically significant maximum changes given here. 8 Only significant change in October 1993 given here, where females after moult to adult were followed through time. 9 Weight changes from their Table 3. 10 Changes in body weight derived from their Table 5 by comparing mean weights of wild females collected on 21 February (as Time 0 values) against weights after egg production experiments; duration of egg production taken from Table 4 for each individual; females with large oocytes were selected for incubation, whereas wild females (with no apparent selection) were used for Time 0 to determine weight loss during incubation. 11 Weight changes derived from Table 1. Adult females were believed to be the predominant stage for this species ( $T$. Ikeda pers. comm.). 12 Data taken from their Table 1, maximum loss given here, with wild controls used as Time 0 weights; 13 Lipid loss predicted from their empirical equation: lipid content $(\mathrm{mg})=$ $0.034 \mathrm{e}^{-0.208}$ days .14 Weight change taken as difference between fed and starved individuals. 15 Weight changes taken from their Table 3. 16 Values taken from their Table 8, only total lipid values presented, as dry weight values increased. Starvation defined by authors as placing copepods in surface water passed through a $35 \mu \mathrm{m}$ mesh net, assuming that the material passing through this mesh is unimportant to these large carnivores. 17 Weight changes taken from their text. 18 Only maximum changes given here, K. Swadling pers. comm

\begin{tabular}{|c|c|c|c|c|c|c|c|}
\hline Species & $\begin{array}{l}\text { Incubation } \\
\text { conditions }\end{array}$ & $\begin{array}{l}\text { iitial wt }\left(\mu \mathrm{g} \text { ind }^{-1}\right) \\
\quad(\text { Time 0) }\end{array}$ & $\begin{array}{c}\text { Final wt }\left(\mu \mathrm{g} \text { ind } .^{-1}\right) \\
(\text { Time } t)\end{array}$ & Units & $\begin{array}{l}\text { Time } t \\
\text { (d) }\end{array}$ & $\begin{array}{l}\text { \% Change from } \\
\text { initial wt }\end{array}$ & Source \\
\hline \multicolumn{8}{|c|}{$\begin{array}{l}\text { INCUBATED POPULATIONS } \\
\text { With food supplied }\end{array}$} \\
\hline Acartia australis & Ambient seawater & 7.92 & 3.22 & Pro & 1.79 & -59.3 & $\begin{array}{l}\text { Ikeda \& } \\
\text { Skjoldal } 1980^{1}\end{array}$ \\
\hline Acartia bifilosa & $\begin{array}{l}5 \mu \mathrm{g} \mathrm{chl} \mathrm{a} \mathrm{l}^{-1} \text { culture } \\
10 \mu \mathrm{g} \mathrm{chl} \mathrm{a} \mathrm{l}^{-1} \text { culture } \\
14 \mu \mathrm{ghl} \mathrm{l}^{-1} \text { culture } \\
19 \mu \mathrm{g} \mathrm{chl} \mathrm{a} \mathrm{l}^{-1} \text { culture } \\
24 \mu \mathrm{g} \mathrm{chl} \mathrm{a} \mathrm{l}^{-1} \text { culture } \\
\text { Ambient seawater }\end{array}$ & $\begin{array}{l}2.1 \\
2.1 \\
2.1 \\
2.1 \\
2.1 \\
1.4 \\
1.4 \\
1.4 \\
1.4 \\
1.4 \\
2.2 \\
1.7\end{array}$ & $\begin{array}{l}2.3 \\
2.2 \\
2.3 \\
2.4 \\
2.6 \\
1.5 \\
1.5 \\
1.1 \\
1.1 \\
1.6 \\
1.6 \\
1.5\end{array}$ & $\begin{array}{l}\mathrm{C} \\
\mathrm{C} \\
\mathrm{C} \\
\mathrm{C} \\
\mathrm{C} \\
\mathrm{C} \\
\mathrm{C} \\
\mathrm{C} \\
\mathrm{C} \\
\mathrm{C} \\
\mathrm{C} \\
\mathrm{C}\end{array}$ & $\begin{array}{c}3.33 \\
3.33 \\
3.33 \\
3.33 \\
3.33 \\
3.33 \\
3.33 \\
3.33 \\
3.33 \\
3.33 \\
2 \\
2\end{array}$ & $\begin{array}{r}9.5 \\
4.8 \\
9.5 \\
14.3 \\
23.8 \\
7.1 \\
7.1 \\
-21.4 \\
-21.4 \\
14.3 \\
-27.3 \\
-11.8\end{array}$ & $\begin{array}{l}\text { Koski \& } \\
\text { Kuosa } \\
(1999)^{2}\end{array}$ \\
\hline Acartia hudsonica & Ambient seawater & $\begin{array}{r}10.93 \\
5.31 \\
5.56 \\
1.24\end{array}$ & $\begin{array}{r}12.77 \\
6.61 \\
4.88 \\
1.47\end{array}$ & $\begin{array}{l}\text { DW } \\
\text { C } \\
\text { C } \\
\text { N }\end{array}$ & $\begin{array}{l}2 \\
2 \\
2 \\
2\end{array}$ & $\begin{array}{r}16.8 \\
24.5 \\
-12.2 \\
18.5\end{array}$ & \multirow{2}{*}{$\begin{array}{l}\text { Durbin et } \\
\text { al. }(1992)^{3}\end{array}$} \\
\hline Acartia hudsonica & $\begin{array}{l}\text { Algae-enriched } \\
\text { seawater }\end{array}$ & $\begin{array}{r}10.93 \\
3.98 \\
5.56 \\
1.08 \\
1.50\end{array}$ & $\begin{array}{r}13.09 \\
4.72 \\
4.78 \\
1.31 \\
1.36\end{array}$ & $\begin{array}{l}\text { DW } \\
\text { C } \\
\mathrm{C} \\
\mathrm{N} \\
\mathrm{N}\end{array}$ & $\begin{array}{l}2 \\
2 \\
2 \\
2 \\
2\end{array}$ & $\begin{array}{r}19.8 \\
18.6 \\
-14.0 \\
21.3 \\
-9.3\end{array}$ & \\
\hline Acartia hudsonica & $\begin{array}{l}\text { Low concentrations } \\
\text { of algae }\end{array}$ & 12.11 & 8.49 & DW & 7 & -29.9 & $\begin{array}{l}\text { Durbin } \\
\text { et al. }(1992)^{4}\end{array}$ \\
\hline Acartia hudsonica & $\begin{array}{l}\text { High concentration } \\
\text { of algae }\end{array}$ & $\begin{array}{l}3.98 \\
1.08\end{array}$ & $\begin{array}{l}4.72 \\
1.31\end{array}$ & $\begin{array}{l}\mathrm{C} \\
\mathrm{N}\end{array}$ & $\begin{array}{l}2 \\
2\end{array}$ & $\begin{array}{l}18.6 \\
21.3\end{array}$ & \multirow{2}{*}{$\begin{array}{l}\text { Durbin \& } \\
\text { Durbin } \\
(1992)^{\mathbf{5}}\end{array}$} \\
\hline Acartia hudsonica & $\begin{array}{l}\text { High concentration } \\
\text { of algae }\end{array}$ & $\begin{array}{l}5.54 \\
1.46\end{array}$ & $\begin{array}{l}7.02 \\
1.64\end{array}$ & $\begin{array}{l}\mathrm{C} \\
\mathrm{N}\end{array}$ & $\begin{array}{l}4 \\
4\end{array}$ & $\begin{array}{l}26.7 \\
12.3\end{array}$ & \\
\hline Acartia tonsa & $\begin{array}{l}\text { Algae-enriched } \\
\text { seawater }\end{array}$ & 11.8 & 13.2 & DW & 2 & 11.9 & $\begin{array}{l}\text { Durbin et } \\
\text { al. }(1983)^{6}\end{array}$ \\
\hline Acartia tonsa & Algae culture & $\begin{array}{l}9.9 \\
3.32 \\
0.95\end{array}$ & $\begin{array}{l}14.3 \\
5.35 \\
1.31\end{array}$ & $\begin{array}{l}\text { DW } \\
\text { C } \\
\text { N }\end{array}$ & $\begin{array}{l}1 \\
1 \\
1\end{array}$ & $\begin{array}{l}44.4 \\
61.1 \\
37.9\end{array}$ & $\begin{array}{l}\text { Thompson } \\
\text { et al. } \\
(1994)^{7}\end{array}$ \\
\hline
\end{tabular}


Table 3 (continued)

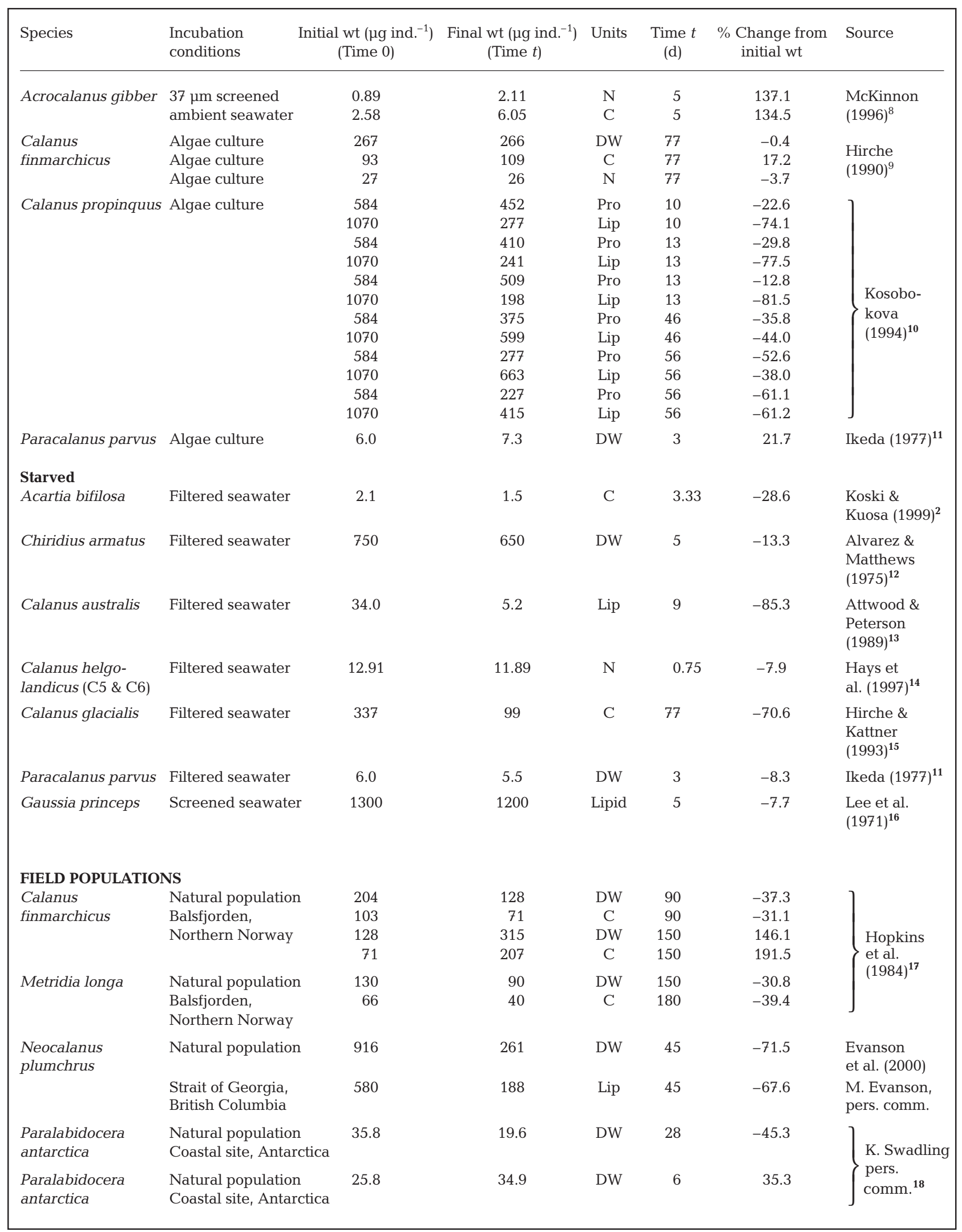


Table 4. Carbon and nitrogen content of adult female copepods in different stages of ovarian ripeness. Weights for ovigerous Calamoecia trifida include body and attached egg mass, see 'Results' for details. Results from paired $t$-tests included: ns: not significant at $\mathrm{p}<0.05$

\begin{tabular}{|c|c|c|c|c|c|c|c|c|c|c|c|c|}
\hline \multirow[t]{2}{*}{ Reproductive stage } & \multicolumn{4}{|c|}{ Carbon wt ( $\mu \mathrm{g} \mathrm{C}$ ind..$\left.^{-1}\right)$} & \multicolumn{8}{|c|}{ Nitrogen wt ( $\mu \mathrm{g} \mathrm{N}$ ind.$\left.^{-1}\right)$} \\
\hline & $\bar{x}$ & SD & $\mathrm{n}$ & $t$-test $\mathrm{p}$ & & & $\bar{x}$ & $\mathrm{SD}$ & $\mathrm{n}$ & $t$-test $\mathrm{p}$ & & \\
\hline \multicolumn{13}{|l|}{ Scolecithrix danae } \\
\hline Immature & 72.49 & 18.92 & 5 & $0.054 \mathrm{~ns}$ & & & 13.63 & 2.55 & 5 & $0.101 \mathrm{~ns}$ & & \\
\hline Medium & 97.56 & 18.48 & 6 & & 0.010 & & 16.60 & 2.79 & 6 & & 0.015 & \\
\hline Ripe & 113.26 & 15.53 & 4 & & & $0.200 \mathrm{~ns}$ & 20.42 & 3.85 & 4 & & & $0.104 \mathrm{~ns}$ \\
\hline \multicolumn{13}{|c|}{ Calamoecia trifida } \\
\hline Stripped (removed egg mass) & 1.18 & 0.07 & 5 & $\mid<0.001$ & & & 0.31 & 0.04 & 5 & 0.004 & & \\
\hline Ripe & 2.11 & 0.22 & 6 & & $<0.001$ & & 0.48 & 0.09 & 6 & & 0.001 & \\
\hline Ovigerous (with egg mass) & 2.10 & 0.21 & 5 & & & $0.954 \mathrm{~ns}$ & 0.42 & 0.02 & 5 & & & $0.179 \mathrm{~ns}$ \\
\hline
\end{tabular}

at Time 0 and 50 at Time $t$ ), and sometimes $<15$. This often rises to $>1000$ replicates to detect a $1 \%$ change, and for 19 of the 33 cases examined here it was $>10000$. This seems impractical to undertake using standard methods.

\section{DISCUSSION}

In the 'Hypothetical populations' section (see 'Results') we explore a situation whereby adult body mass is cyclical, being steady-state from one point in the eggspawning cycle to the equivalent point in the next spawning period. Body weight increases to the point of egg output, when this accumulated mass is released, producing a 'saw-tooth' pattern. Using this refined description of the mechanism of coupling between growth and egg output in copepods, we demonstrated that although the mean rate of growth may be derived from egg output, when the incubation period is less than the inter-spawn period all individual rates are incorrect, as are the maximum and minimum. When measurements of coefficient of variation in growth are in error, any measurement of variability that relied upon individual rates would also be incorrect. The mean rates are only correct because the individual errors effectively cancel each other out when considering the entire population. As described in the 'Introduction', egg output (production) is measured either through the 'incubation approach' or the 'egg-ratio method'. As the latter method is applied at the population level, it is not used to derive individual rates but only means, hence it does not suffer from the problems associated with incorrectly describing growth rates of individuals (be these maximums, minimums or variability). Although we use a 'saw-tooth' pattern to describe body weight change in these hypothetical individuals the real situation is likely to be much more complex because of minor fluctuations related to feeding and migration cycles, food patchiness, etc.
The results for Calamoecia trifida may be illustrative of the saw-tooth pattern in body weight shown in Fig. 2. The stripped females (i.e. females bearing egg sacs that were removed prior to weight determination) were significantly lighter in carbon and nitrogen terms than the ripe females that were about to release their eggs. Stripped females were also lighter than ovigerous ones weighed with their egg sacs still attached. Ripe females were not significantly different in carbon or nitrogen weight from the egg sac-bearing ovigerous females. For C. trifida, the carbon and nitrogen weight of the egg mass was almost as great as for the body weight of stripped individuals. It may not be usual for clutches to be so heavy in relation to the adult body, although values of 35 to $60 \%$ have been observed in other tropical egg-carriers (Hopcroft \& Roff 1996). Operationally, such heavy clutches have made it easier to measures significant changes. However, this does not detract from the possibility of saw-tooth patterns of weight changes occurring in those species bearing light egg masses, or in clutch-producing broadcasters too.

It is not only reproductively active adult females that may gain and lose weight, but also pre- and post-reproductive adults, which are attributed a zero growth rate using the 'incubation approach' because of zero egg output. Is this an accurate assumption? We have found clear evidence that females may increase and decrease in weight. McKinnon (1996) found that for the small tropical species Acrocalanus gibber grown in mesocosms containing 'natural' water, both carbon and nitrogen body content continued to increase upon moulting to the adult. In 1 case, the nitrogen content of newly moulted females was $0.89 \mu \mathrm{gN}$ ind. ${ }^{-1}$, but their weight continued to increase over the following $5 \mathrm{~d}$ to reach $2.5 \mu \mathrm{gN}$ ind. ${ }^{-1}$. These changes represent increases of 134 and $137 \%$ in carbon and nitrogen body weights respectively, during a period including both a pre-reproductive and reproductively active phase. Such measurements clearly bring into 
Table 5. Comparisons of weight measures and their variability in female copepods. All copepods were Stage C6 except where indicated. $(\mathrm{SD}=$ is the standard deviation of samples when number of individuals per replicate $\mathrm{r}=1$, $\mathrm{SE}=$ standard error of means when $r>1$; variance is the SD or SE squared). No. of replicates needed to allow discrimination of 1 and $10 \%$ changes in body weight are given (i.e. where a $t$-test would detect a weight change $90 \%$ of the time, with $\mathrm{p}<0.05$ defining significant difference); e.g. value of 50 would equate to 25 initial replicates and 25 at the end of the period; Replicates needed: we assumed that the variance for the population after the change was equal to that before (hence the within-population variability is derived as the variances multiplied by 2)

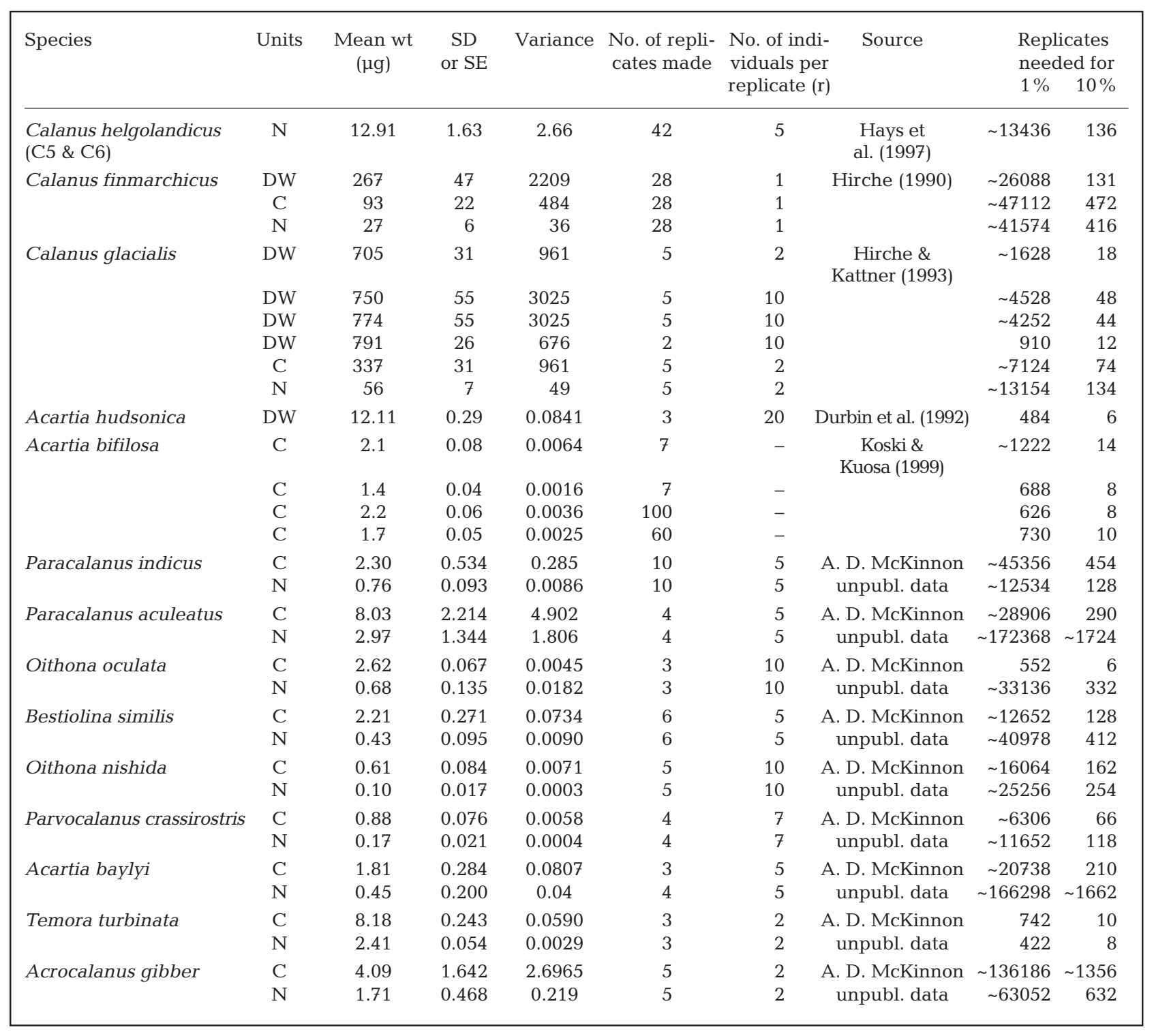

doubt the assumption that adult female body weight increases are very limited because of their rigid exoskeleton and inability to moult. It is not possible to relate the other increases and decreases in weight given in Tables $2 \& 3$ to whether females were pre- or post-reproductive. The results from measurements on Scolecithrix danae at different stages of reproductive maturity provide evidence that females can put on weight over the period from reproductive immaturity to ripeness. Because this species was collected in a tropical region, it is clear that such weight changes are not only limited to large species in cold waters. In this case, body carbon increased by $56 \%$ for adult females with immature ovaries through to ripeness, and nitrogen increased by $50 \%$ for the same developmental stages.

When measuring egg production rates, it is not uncommon to incubate Calanus helgolandicus (e.g. Bautista et al. 1994, Pond et al. 1996), or larger Calanus species such as C. finmarchicus (e.g. Plourde \& Runge 
1993), C. glacialis (e.g. Hirche et al. 1994) and C. hyperboreus (e.g. Hirche \& Kattner 1993) in food-free (e.g. GF/C- or GF/F-filtered) seawater. Laabir et al. (1995) found that during $24 \mathrm{~h}$ incubations of C. helgolandicus, eggs were produced at the same rate in both filtered and natural seawater. Similarly, Plourde \& Runge (1993) found that C. finmarchicus collected from the lower St. Lawrence Estuary and incubated for $24 \mathrm{~h}$ usually had similar rates of egg production regardless of whether they were incubated in foodenriched or filtered seawater. Tester \& Turner (1990) showed that radioactive carbon introduced in the food of Acartia tonsa could be measured in newly produced eggs in less than $10 \mathrm{~h}$. The time taken for $\mathrm{C}^{14}$ label in eggs to reach a maximum was only $9.5 \mathrm{~h}$ for $A$. tonsa and $16.5 \mathrm{~h}$ for Centropages velificatus, but $65.5 \mathrm{~h}$ for Labidocera aestiva, $89 \mathrm{~h}$ for Centropages typicus, and $91 \mathrm{~h}$ for Anomalocera ornata. Although these results may be indicative of tight coupling between feeding and egg output in the smaller species, this is not in itself evidence that body weights are in steady-state. When eggs continue to be shed at rates that are independent of food supplied for many hours to days (as detailed above), and when there may be many hours to days before food ingested appears in eggs, there is a strong indication of de-coupling of ingestion and egg output, at least over the short-term. The fact that when previously starved adult females are given food there may be a significant period of time before eggs are produced (e.g. Hirche \& Bohrer 1987, Peterson 1988, Ohman et al. 1998) may also be indicative of body weight not being in steady-state. Presumably, in this period, body weight increases may be important and related to re-development of body reserves, gonad reestablishment and egg development. Copepods have been shown to utilise body proteins and sterols for egg production when food is of poor quality (Durbin et al. 1983). In a study of adult female A. hudsonica from Narraganset Bay, Durbin et al. (1992) found significant increases or decreases in dry weight, carbon or nitrogen on 5 of the 17 examinations (see their Table 2). Adults lost up to $30 \%$ of their own body weight when subjected to poor food conditions. Whereas upper limits to increasing body weight might be controlled by the restrictions placed by the exoskeleton, negative growth is not-rather, this might be limited by the amount of storage products as well as other physiological constraints.

Results from the compilation of laboratory and field studies demonstrate that the body weights of female copepods can change greatly when incubated under natural and artificial feeding conditions. Losses and gains of nitrogen, carbon, lipid and protein have been observed over short incubations. Weight increases of $>100 \%$ and decreases of $>30 \%$ have been demon- strated (Table 3). In some cases such body weight changes may be attributable to dramatic changes in food, turbulence, encounter rates or other environmental conditions associated with taking an animal from the environment and incubating it. In the studies compiled here, many investigators examined body weight changes that occured as a result of starvation or when food was added to superabundance. Such studies may give insight into the tolerances of the animals, but may not necessarily reflect usual weight changes.

The environment that animals experience in nature may change extremely rapidly as a result of physical, chemical and biological changes. Concentrations of chlorophyll a may vary by orders of magnitude as a result of phytoplankton blooms in the space of a few days (Durbin et al. 1983, Plourde \& Runge 1993, Kiørboe \& Nielsen 1994) as may particulate carbon and nitrogen concentrations (Durbin et al. 1983). Natural spatial and temporal patchiness of food may result in animals experiencing very different food quality/ quantities through their life. Alarmingly, the only studies of weight changes that we have encountered in which adult copepods were incubated in natural food assemblages collected from the same location as the copepods were those of Durbin et al. (1992), McKinnon (1996) and Koski \& Kuosa (1999).

Weight changes associated with reproductive maturity have been mentioned in numerous studies. A characteristic feature of polar and sub-polar herbivorous copepods is the utilisation of their large lipid reserves for basic metabolic needs to allow survival during periods of food scarcity (Lee et al. 1971). The elevated levels of lipid storage of high-latitude species has also been suggested to be representative of a reproductive strategy adapted to marked seasonality (Båmstedt 1986). Plourde \& Runge (1993) found that the oil sac/body volume ratio of adult female Calanus finmarchicus decreased by 30 to $40 \%$ prior to the spring bloom, with this change being associated with gonad maturation. Most Arctic species continue to produce eggs when incubated in the absence of food over long periods, even months. C. hyperboreus and C. glacialis may naturally mature and spawn on stored energy alone, often in 'anticipation' of the spring bloom, although egg production increases when there is available food (Conover 1962, 1967, Smith 1990, Hirche 1991, Conover \& Siferd 1993, Hirche \& Kattner 1993).

In the absence of food, egg production relies on stored energy, mostly wax esters deposited during the feeding period, and body protein for nitrogen supply (Hirche \& Niehoff 1996). Females may continually produce eggs almost completely at the expense of whole adult weight over long periods. Conover (1967) states that 'Spent females (of Calanus hyperboreus) in nature are nearly transparent and almost devoid of internal 
structure. They may weight only $10 \%$ as much as a similar sized individual just after the spring bloom.' Conover \& Siferd (1993) later observed C. hyperboreus dry weight to decline from 6 to $1 \mathrm{mg}$ over a $3 \mathrm{mo}$ period. The same appears to be true for Neocalanus cristatus (Fulton 1973); for this species and its congener $N$. plumchrus, negative growth must be considered the norm since females do not feed (Beklemishev 1954).

In the Antarctic, Calanoides acutus sexually matures and commences egg production when there is little or no food by utilising internal energy reserves (Hagen \& Schnack-Schiel 1996). Similarly, adult females of $C$. propinquus in the Weddell Sea may complete gonad formation and commence spawning before the onset of the spring phytoplankton bloom (Hagen \& SchnackSchiel 1996). This period is characterised by decreasing lipid content and dry mass in early spring. However, at other times of the year egg production is more closely coupled to feeding. Adult females of other polar species are also suspected of accumulating large lipid reserves and using these during the period of egg production, e.g. Metridia gerlachei. Indeed, Calbet \& Irigoien (1997) expressed concern that egg production rates may not truly reflect ingestion rates and other metabolic processes in this species because lipid stores may be used as some form of buffer, allowing decoupling of immediate ingestion and egg production rates. Under circumstances where no food is being assimilated, total net growth must be negative given the respiration demands of starved individuals. Egg output rates in such situations clearly represent a de-coupling of growth from food supply and not net growth rates.

Such situations are not limited to high latitudes. In the Californian upwelling system, Eucalanus californicus continues to increase the amount of lipid storage on moulting to $\mathrm{C} 6$, and commencement of egg production is delayed (Smith \& Lane 1991). They suggested that the accumulation of lipids and gonad maturation (and later egg production) were occurring simultaneously. The lipid and wax ester content of Calanus helgolandicus declines from immature to mature females (Gatten et al. 1980). Neocalanus tonsus reproduce at depths of 500 to $1000 \mathrm{~m}$ in the winter, relying upon lipid reserves (Ohman 1987). Abou Debs (1979) reports that for laboratory incubations over $6 \mathrm{~d}$ with $8 \times$ $10^{3}$ cells $\mathrm{ml}^{-1}$ of Hymenomonas elongata, the lipid content of Temora stylifera increased from 11 to $15 \%$ of the initial dry weight.

\section{Recommendations for new protocols}

The use of egg output from incubations of individual animals may not be reliable at giving individual rates of growth if these species are producing eggs discon- tinuously, with an inter-spawn period longer than the incubation period, or if females are utilising stored resources or indeed adding body reserves. Although data on individuals or small groups of several individuals have been used to describe rates of maximum or minimum growth (e.g. Hay 1995, Nielsen \& Hansen 1995, Saiz et al. 1999) or individual variability in growth (e.g. Richardson \& Verheye 1999), unless the incubation period is equal to or a whole-number multiple of the inter-spawn period, such results may not be valid. There may be a large number of individuals within an adult population that produce no eggs over a $24 \mathrm{~h}$ incubation period. These may be pre- or postreproductive adults, those not able to produce eggs, or reproductively active females for which the period of incubation is shorter than the inter-spawn period. In some studies in which individuals have been incubated, zero egg production results were excluded prior to the derivation of the mean growth rate of adults (e.g. Hopcroft \& Roff 1998). The saw-tooth concept of body weight change exemplifies why those individuals not producing eggs should be included when deriving mean growth rates. If these are excluded, the mean growth rates for the egg-producing group can be an overestimate of the actual mean growth rate for this same group.

Errors associated with the saw-tooth growth and egg release pattern might potentially be solved in 2 ways. Firstly, if one were to measure changes in individual body weights in addition to egg output, net growth at the individual level could be correctly derived. Secondly, if one were to incubate individuals over a period equal to or a whole-number multiple of the interspawn period, egg output would give correct individual growth rates (so long as body weights are steadystate at similar points on the inter-spawn period, example B in Fig. 1). This is still problematic however, because inter-spawn periods vary spatio-temporally and between individuals. Unfortunately, the longer the incubation the greater the incubation conditions may diverge from those in situ. If one incubates a large enough number of individuals (a very important issue especially when spawning is infrequent) and body weight is steady-state over the scale of the spawning period, then mean growth rates derived from egg output will still be accurate, even if the incubation period is less than the inter-spawn period.

Several workers have examined egg output and either measured or derived ingestion rates simultaneously, in an attempt to determine whether the latter are sufficient to meet the requirements of the former, or whether egg production must be fuelled in part from body weight reserves (e.g. Ward \& Shreeve 1995, Cabal et al. 1997). Such approaches have usually assumed values for assimilation and gross growth effi- 
ciencies. A more direct way of determining whether ingestion demands meet those of egg output (production), would simply be to take account of the total weight change. We are not aware of any investigations in polar or sub-polar regions in which adult female copepod production has been measured taking into account both egg output and body weight changes. Some workers have examined ingestion and egg production and derived egg production efficiencies (e.g. Checkley 1980, Kiørboe et al. 1985, Peterson 1988). Abou Debs (1984), working on laboratory carbon and nitrogen budgets for Temora longicornis, found that $\mathrm{C}$ and $\mathrm{N}$ ingestion was much higher than the cost of metabolism, egestion and reproduction. Although the author states that 'in adults there should be no net growth' (presumably meaning body weight increase), he goes on to consider that lipid content as a percentage of animal dry weight may indeed have increased. If adult body weights are not in steady-state, and endogenous as well as exogenous supplies of elements such as carbon and nitrogen are not considered, then clearly the results may be inaccurate. Indeed, Durbin \& Durbin (1992) have used this argument to draw into doubt results from the study of Kiørboe et al. (1985), stating 'The significance of short-term weight changes for energy budget calculations can be estimated from the detailed study of $A$. tonsa bioenergetics at $18^{\circ} \mathrm{C}$ by Kiørboe et al. (1985)'. Durbin \& Durbin's own data indicate that at the lowest food levels most respired carbon and excreted nitrogen was from body-tissue catabolism rather than from food ingestion as was assumed in the assimilation efficiency calculations of Kiørboe et al. (1985).

Ideally, the weight of single individuals would be followed through time, thus eliminating problems of population variance that hinder results from sacrificial methods of weight determination (see last sub-section of 'Results'). However, seasonal studies have shown that large weight changes in a species through the year may only be reflected by very small prosome length changes (Bottrell \& Robins 1984). Furthermore, relatively large changes in the body weights of individual copepods may accompany only small changes in body length (Durbin et al. 1992, McKinnon 1996), and statistically significant changes in body carbon, nitrogen and dry weight may not accompany significant changes in prosome length (Thompson et al. 1994). Unfortunately the most accurate methods available for determination of body weight are destructive. We are therefore at present unable to follow the weight of one individual through time, and instead are forced to use methods whereby animals are sacrificed from a population over time.

A factor of particular importance is that interindividual variation in body weight may be high, and if sample size is low, then detection of body weight changes may be obscured (i.e. a Type II error may arise). This needs to be considered in the experimental design. As is apparent from Table 5, to measure changes in body weight of $1 \%$, when growth rates are of a similar percentage of body weight, would be impractical. Fortunately, egg production rates are often $>10 \%$ of body weight $\mathrm{d}^{-1}$, although growth rates $<10 \%$ are not uncommon in temperate (e.g. Hay et al. 1991, Peterson et al. 1991, Checkley et al. 1992, Kiørboe \& Nielsen 1994, Rodríguez et al. 1995), sub-polar/polar regions (e.g. Hirche et al. 1991, Hassett et al. 1993), or oligotrophic environments (e.g. Calbet et al. 1996, McKinnon \& Ayukai 1996, Calbet \& Agustí 1999), and are especially common in many adults with body weights $>10 \mu \mathrm{gC}$ ind. $^{-1}$ (see Hirst \& Lampitt 1998). The extent of replication necessary to detect a $10 \%$ change in body weight may be practical, i.e. often $<100$ determinations (50 at Time 0 and 50 at Time $t$ ), and sometimes $<15$ (see Table 5), but appear impractical for $1 \%$ change.

Tester \& Turner (1990) state that 'If relationships between copepod egg production and feeding rates are temporally uncoupled, this precludes the use of egg production as an index of feeding'. We go further and suggest that egg production may not only be decoupled from feeding, but from growth too. Using egg output measurements without consideration of body weight change probably does not allow accurate estimation of net growth in copepods, and future investigations should assess changes in body weight. Keeping individuals in food-free seawater is obviously unsuitable when attempting to measure body weight changes, and incubation containers should be large enough to ensure that the concentration of phytoplankton, microzooplankton and other prey components changes by only a minimal amount during incubation. Attempting to measure changes in adult weight makes the incubation even more critical. For example Ikeda \& Skjoldal (1980) related changes in Acartia australis protein weight to reduced feeding conditions, even though the incubations were in natural seawater collected at the same site where copepods were captured. Ikeda (1977) described the difficulties in collecting animals from the environment without physiological consequences. The weight of material in the copepod gut and its variability may be an additional complication. For example, the maximum gut content of Centropages typicus is $12 \mathrm{ng}$ of chlorophyll a for a female weighing $16.7 \mu \mathrm{gC}_{i}$ using a carbon:chlorophyll a ratio of 50 this equates to $600 \mathrm{ngC}$, or $3.6 \%$ of its body carbon weight (derived by Sciandra et al. 1990 from the data of Dagg \& Gill 1980). It thus appears a necessity to allow animals a brief but sufficient period in which to empty their guts prior to weight determination. 
The steady-state assumption for adult female body size has been recognised as a problem in those larger species that contain or can potentially contain large lipid reserves. Several workers have also shown that this assumption may not always be valid even in those species not typically regarded as having de-coupled feeding and spawning, such as small temperate and tropical species. In the future, if we wish to derive accurate estimates of growth in natural populations of copepods, we cannot limit ourselves to measurements of egg output alone. There are very few studies where changes in body weights of females have been examined and more work of this type is urgently needed if we are to appreciate how accurately egg output terms equate to net growth of adult females.

Acknowledgements. We wish to thank all those who were so generous in donating data or giving information from their work. Comments by Angus Atkinson, Adrian Bunker, Shinichi Uye, Peter Ward and anonymous reviewers improved an earlier version of the manuscript. We thank Samantha Duggan for carbon and nitrogen analyses. AGH was supported by the Nuffield Foundation (NUF-NAL 99), and the NERC thematic programme 'Marine Productivity' (GST/02/2767).

\section{LITERATURE CITED}

Abou Debs C (1979) Aspects de la physiologie et de la biologie de Temora stylifera Dana (copépode calanoide): éléments du bilan en carbone et en azote et optimisation de la fertilité. Thèse de $3^{\text {ème }}$ cycle. Université $\mathrm{P}$. et $\mathrm{M}$. Curie, Paris

Abou Debs C (1984) Carbon and nitrogen budget of the calanoid copepod Temora stylifera: effect of concentration and composition of food. Mar Ecol Prog Ser 15:213-223

Alvarez V, Matthews JBL (1975) Experimental studies on the deep-water pelagic community of Korsfjorden, Western Norway. Feeding and assimilation by Chiridius armatus (Crustacea, Copepoda). Sarsia 58:67-78

Ambler JW, Ferrari F, Fornshell JA, Buskey EJ (1999) Diel cycles of molting, mating, egg sac production and hatching in the swarm forming cyclopoid copepod Dioithona oculata. Plankton Biol Ecol 46:120-127

Andersen CM, Nielsen TG (1997) Hatching rate of the eggcarrying estuarine copepod Eurytemora affinis. Mar Ecol Prog Ser 160:283-289

Armstrong DA, Verheye HM, Kemp AD (1991) Short-term variability during an Anchor Station study in the southern Benguela upwelling system. Fecundity estimates of the dominant copepod, Calanoides carinatus. Prog Oceanogr 28:167-188

Attwood CG, Peterson WT (1989) Reduction in fecundity and lipids of the copepod Calanus australis (Brodskii) by strongly pulsed upwelling. J Exp Mar Biol Ecol 129: 121-131

Båmstedt U (1986) Chemical composition and energy content. In: Corner EDS, O'Hara SCM (eds) The biological chemistry of marine copepods. Clarendon Press, Oxford, p 1-58

Bautista B, Harris RP, Rodriguez V, Guerrero F (1994) Temporal variability in copepod fecundity during two different spring bloom periods in coastal waters off Plymouth (SW England). J Plankton Res 16:1367-1377
Beklemishev KV (1954) Feeding of some mass planktonic copepods in far eastern waters. Zool Zh 33:1210-1230 (in Russian)

Berggreen U, Hansen B, Kiørboe T (1988) Food size spectra, ingestion and growth of the copepod Acartia tonsa during development: implications for determination of copepod production. Mar Biol 99:341-352

Bottrell HH, Robins DB (1984) Seasonal variations in length, dry weight, carbon and nitrogen of Calanus helgolandicus from the Celtic Sea. Mar Ecol Prog Ser 14:259-268

Cabal J, Harris LR, Head EJH (1997) Egg production rates of Calanus finmarchicus in the Northwest Atlantic (Labrador Sea). Can J Fish Aquat Sci 54:1270-1279

Calbet A, Agustí S (1999) Latitudinal changes of copepod egg production rates in Atlantic waters: temperature and food availability as the main driving factors. Mar Ecol Prog Ser 181:155-162

Calbet A, Irigoien X (1997) Egg and faecal pellet production rates of the marine copepod Metridia gerlachei northwest of the Antarctic Peninsula. Polar Biol 18:273-279

Calbet A, Trepat I, Arin L (2000) Naupliar growth versus egg production in the calanoid copepod Centropages typicus. J Plankton Res 22:1393-1402

Calbet A, Alcaraz M, Saiz E, Estrada M, Trepat I (1996) Planktonic herbivorous food webs in the Catalan Sea (NW Mediterranean): temporal variability and comparison of indices of phyto-zooplankton coupling based on state variables and rate processes. J Plankton Res 18:2329-2347

Carlotti F, Hirche H-J (1997) Growth and egg production of female Calanus finmarchicus: an individual-based physiological model and experimental validation. Mar Ecol Prog Ser 149:91-104

Carlotti F, Rey C, Javanshir A, Nival S (1997) Laboratory studies on egg and faecal pellet production of Centropages typicus: effect of age, effect of temperature, individual variability. J Plankton Res 19:1143-1165

Checkley DM Jr (1980) The egg production of a marine planktonic copepod in relation to its food supply: laboratory studies. Limnol Oceanogr 25:430-446

Checkley DM Jr, Dagg MJ, Uye SI (1992) Feeding, excretion and egg production by individuals and populations of the marine, planktonic copepods, Acartia spp. and Centropages furcatus. J Plankton Res 14:71-96

Chisholm LA, Roff JC (1990) Abundances, growth rates, and production of tropical neritic copepods off Kingston, Jamaica. Mar Biol 106:79-89

Conover RJ (1962) Metabolism and growth in Calanus hyperboreus in relation to its life cycle. Rapp P-v Réun Cons Perm Int Explor Mer 153:190-197

Conover RJ (1967) Reproductive cycle, early development, and fecundity in laboratory populations of the copepod Calanus hyperboreus. Crustaceana 13:61-72

Conover RJ, Siferd TD (1993) Dark-season survival strategies of coastal zone zooplankton in the Canadian Arctic. Arctic 46:303-311

Corner EDS, Head RN, Kilvington CC, Pennycuick L (1976) On the nutrition and metabolism of zooplankton. 10. Quantitative aspects of Calanus helgolandicus feeding as a carnivore. J Mar Biol Assoc UK 56:345-358

Dagg MJ, Gill DW (1980) Natural feeding rates of Centropages typicus females in the New York Bight. Limnol Oceanogr 25:597-609

Diel S, Tande K (1992) Does the spawning of Calanus finmarchicus in high latitudes follow a reproducible pattern? Mar Biol 113:21-31

Durbin EG, Durbin AG (1992) Effects of temperature and food abundance on grazing and short-term weight changes in 
the marine copepod Acartia hudsonica. Limnol Oceanogr 37:361-378

Durbin EG, Durbin AG, Smayda TJ, Verity PG (1983) Food limitation of production by adult Acartia tonsa in Narragansett Bay, Rhode Island. Limnol Oceanogr 28: $1199-1213$

Durbin EG, Durbin AG, Campbell RG (1992) Body size and egg production in the marine copepod Acartia hudsonica during a winter-spring diatom bloom in Narragansett Bay. Limnol Oceanogr 37:342-360

Evanson M, Borhold EA, Goldblatt RH, Harrison PJ, Lewis AG (2000) Temporal variation in body composition and lipid storage of the overwintering, subarctic copepod Neocalanus plumchrus in the Strait of Georgia, British Columbia (Canada). Mar Ecol Prog Ser 192:239-247

Fulton J (1973) Some aspects of the life history of Calanus plumchrus in the Strait of Georgia. J Fish Res Board Can 30:811-815

Gatten RR, Sargent JR, Forsberg TEV, O'Hara SCN, Corner EDS (1980) On the nutrition of zooplankton. XIV. Utilization of phytoplankton by Calanus helgolandicus during maturation and reproduction. J Mar Biol Assoc UK 60: 391-399

Hagen WM, Schnack-Schiel SB (1996) Seasonal lipid dynamics in dominant Antarctic copepods: energy for overwintering or reproduction? Deep-Sea Res 43:139-158

Hassett RP, Duggins DO, Simenstad CA (1993) Egg production rates of the neritic marine copepod Acartia tumida Willey in the Aleutian Archipelago. Polar Biol 13:515-523

Hay S (1995) Egg production and secondary production of common North Sea copepods: field estimates with regional and seasonal comparisons. ICES J Mar Sci 52: 315-327

Hay SJ, Kiørboe T, Matthews A (1991) Zooplankton biomass and production in the North Sea during the autumn circulation experiment, October 1987-March 1988. Cont Shelf Res 11:1453-1476

Hays GC, Harris RP, Head RN, Kennedy H (1997) A technique for the in situ assessment of the vertical nitrogen flux caused by the diel vertical migration of zooplankton. Deep-Sea Res Part I 44:1085-1089

Hirche HJ (1989) Egg production of the Arctic copepod Calanus glacialis: laboratory experiments. Mar Biol 103: 311-318

Hirche HJ (1990) Egg production of Calanus finmarchicus at low temperature. Mar Biol 106:53-58

Hirche HJ (1991) Distribution of dominant calanoid copepod species in the Greenland Sea during late fall. Polar Biol 11: 351-362

Hirche HJ (1996) The reproductive biology of the marine copepod, Calanus finmarchicus - a review. Ophelia 44: 111-128

Hirche HJ, Bohrer RN (1987) Reproduction of the arctic copepod Calanus glacialis in Fram Strait. Mar Biol 94:11-17

Hirche HJ, Kattner G (1993) Egg production and lipid content of Calanus glacialis in spring: indication of a food-dependent and food-independent reproductive mode. Mar Biol 117:615-622

Hirche HJ, Niehoff B (1996) Reproduction of the Arctic copepod Calanus hyperboreus in the Greenland Sea-field and laboratory observations. Polar Biol 16:209-219

Hirche HJ, Baumann MEM, Kattner G, Gradinger R (1991) Plankton distribution and the impact of copepod grazing on primary production in Fram Strait, Greenland Sea. J Mar Syst 2:477-494

Hirche HJ, Hagen W, Mumm N, Richter C (1994) The Northeast water polynya, Greenland Sea. III. Meso- and macro- zooplankton distribution and production of dominant herbivorous copepods during spring. Polar Biol 14:491-503

Hirst AG, Lampitt RS (1998) Towards a global model of in situ weight-specific growth in marine planktonic copepods. Mar Biol 132:247-257

Hopcroft RR, Roff JC (1996) Zooplankton growth rates: diel egg production in the copepods Oithona, Euterpina and Corycaeus from tropical waters. J Plankton Res 18: 789-803

Hopcroft RR, Roff JC (1998) Zooplankton growth rates: the influence of female size and resources on egg production of tropical marine copepods. Mar Biol 132:79-86

Hopkins CCE, Tande KS, Grønvik S (1984) Ecological investigations of the zooplankton community of Balsfjorden, Northern Norway: an analysis of growth and overwintering tactics in relation to niche and environment in Metridia longa (Lubbock), Calanus finmarchicus (Gunnerus), Thysanoessa inermis (Krøyer) and T.raschi (M. Sars). J Exp Mar Biol Ecol 82:77-99

Ikeda T (1977) The effect of laboratory conditions on the extrapolation of experimental measurements to the ecology of marine zooplankton. IV. Changes in respiration and excretion rates of boreal zooplankton species maintained under fed and starved conditions. Mar Biol 41:241-252

Ikeda T, Skjoldal HR (1980) The effect of laboratory conditions on the extrapolation of experimental measurements to the ecology of marine zooplankton. VI. Changes in physiological activities and biochemical components of Acetes sibogae and Acartia australis after capture. Mar Biol 58:285-293

Kiørboe T, Møhlenberg F, Hamburger K (1985) Bioenergetics of the planktonic copepod Acartia tonsa: relation between feeding, egg production and respiration, and composition of specific dynamic action. Mar Ecol Prog Ser 26:85-97

Kiørboe T, Nielsen TG (1994) Regulation of zooplankton biomass and production in a temperate, coastal ecosystem. 1. Copepods. Limnol Oceanogr 39:493-507

Kiørboe T, Sabatini M (1995) Scaling of fecundity, growth and development in marine planktonic copepods. Mar Ecol Prog Ser 120:285-298

Koski M, Kuosa H (1999) The effect of temperature, food concentration and female size on the egg production of the planktonic copepod Acartia bifilosa. J Plankton Res 21: 1779-1789

Kosobokova KN (1994) Reproduction of the calanoid copeopd Calanus propinquus in the southern Weddell Sea, Antarctica: observations in laboratory. Hydrobiologia 292/293: 219-227

Laabir M, Poulet SA, Ianora A (1995) Measuring production and viability of eggs in Calanus helgolandicus. J Plankton Res 17:1125-1142

Landry MR (1978) Population dynamics and production of a planktonic marine copepod, Acartia clausii, in a small temperate lagoon on San Juan Island, Washington. Int Rev gesamten Hydrobiol 63:77-119

Lee RF, Hirota J, Barnett AM (1971) Distribution and importance of wax esters in marine copepods and other zooplankton. Deep-Sea Res 18:1147-1165

Liang D, Uye S (1997) Seasonal reproductive biology of the egg-carrying calanoid copepod Pseudodiaptomus marinus in a eutrophic inlet of the Inland Sea of Japan. Mar Biol 128:409-414

Marcus NH (1985) Endogenous control of spawning in a marine copepod. J Exp Mar Biol Ecol 91:263-269

Marshall SM, Orr AP (1972) The biology of a marine copepod Calanus finmarchicus (Gunnerus). Springer-Verlag, Berlin

Mauchline J (1998) Advances in marine biology: the biology of calanoid copepods, Vol. 33. Academic Press, New York 
McKinnon AD (1996) Growth and development in the subtropical copepod Acrocalanus gibber. Limnol Oceanogr 41:1438-1447

McKinnon AD, Ayukai T (1996) Copepod egg production and food resources in Exmouth Gulf, Western Australia. Mar Freshw Res 47:595-603

McKinnon AD, Klumpp DW (1998) Mangrove zooplankton of North Queensland, Australia. II. Copepod egg production and diet. Hydrobiologia 362:145-160

McLaren IA, Corkett CJ (1981) Temperature-dependent growth and production by a marine copepod. Can J Fish Aquat Sci 38:77-83

Nielsen TG, Hansen B (1995) Plankton community structure and carbon cycling on the western coast of Greenland during and after the sedimentation of a diatom bloom. Mar Ecol Prog Ser 125:239-257

Nielsen TG, Sabatini M (1996) Role of cyclopoid copepods Oithona spp. in North Sea plankton communities. Mar Ecol Prog Ser 139:79-93

Ohman MD (1987) Energy sources for recruitment of the subAntarctic copepod Neocalanus tonsus. Limnol Oceanogr 32:1317-1330

Ohman M, Drits AV, Clarke ME, Plourde S (1998) Differential dormancy of co-occurring copepods. Deep-Sea Res Part II 45:1709-1740

Paul AJ, Coyle KO, Ziemann DA (1990) Variations in egg production rates by Pseudocalanus spp. in a subarctic Alaskan bay during the onset of feeding by larval fish. J Crustac Biol 10:648-658

Peterson WT (1988) Rates of egg production by the copepod Calanus marshallae in the laboratory and in the sea off Oregon, USA. Mar Ecol Prog Ser 47:229-237

Peterson WT, Tiselius P, Kiørboe T (1991) Copepod egg production, moulting and growth rates, and secondary production, in the Skagerrak in August 1988. J Plankton Res 13:131-154

Plourde S, Runge JA (1993) Reproduction of the planktonic copepod Calanus finmarchicus in the Lower St. Lawrence Estuary: relation to the cycle of phytoplankton production and evidence for a Calanus pump. Mar Ecol Prog Ser 102: 217-227

Pond D, Harris R, Head R, Harbour D (1996) Environmental and nutritional factors determining seasonal variability in the fecundity and egg viability of Calanus helgolandicus in coastal waters off Plymouth, UK. Mar Ecol Prog Ser 143: $45-63$

Poulet SA, Ianora A, Laabir M, Klein Breteler WCM (1995) Towards the measurement of secondary production and recruitment in copepods. ICES J Mar Sci 52:359-368

Razouls S (1982) Ètude expérimentale de la ponte de deux copépodes pélagiques Temora stylifera et Centropages typicus. II. Dynamique des pontes. Vie Milieu 32:11-20

Rodríguez V, Guerrero F, Bautista B (1995) Egg production of individual copepods of Acartia grani Sars from coastal waters: seasonal and diel variability. J Plankton Res 17: $2233-2250$

Richardson AJ, Verheye HM (1999) Growth rates of copepods in the southern Benguela upwelling system: the interplay between body size and food. Limnol Oceanogr 44: 382-392

Runge JA (1984) Egg production of the marine, planktonic copepod, Calanus pacificus Brodsky: laboratory observations. J exp mar Biol Ecol 74:53-66

Runge JA (1985) Relationship of egg production of Calanus pacificus to seasonal changes in phytoplankton availability

Editorial responsibility: Otto Kinne (Editor),

Oldendorf/Luhe, Germany in Puget Sound, Washington. Limnol Oceanogr 30:382-396

Runge JA, Roff JC (2000) The measurement of growth and reproductive rates. In: Harris RP, Skjoldal HR, Lenz J, Wiebe P, Huntley M (eds) ICES Zooplankton Methodology Manual. International Council for the Exploration of the Sea, Copenhagen

Sabatini M, Kiørboe T (1994) Egg production, growth and development of the cyclopoid copepod Oithona similis. J Plankton Res 16:1329-1351

Saiz E, Calbet A, Trepat I Irigoien X, Alcaraz M (1997) Food availability as a potential source of bias in the egg production method for copepods. J Plankton Res 19:1-14

Saiz E, Calbet A, Irigoien X, Alcaraz M (1999) Copepod egg production in the western Mediterranean: response to food availability in oligotrophic environments. Mar Ecol Prog Ser 187:179-189

Sciandra A, Gouzé JL, Nival P (1990) Modelling the reproduction of Centropages typicus (Copepoda: Calanoida) in a fluctuating food supply: effect of adaptation. J Plankton Res 12:549-572

Smith SL (1990) Egg production and feeding by copepods prior to the spring bloom of phytoplankton in Fram Strait area of the Greenland Sea. Mar Biol 106:59-69

Smith SL, Lane PVZ (1991) The jet off Point Arena, California: its role in aspects of secondary production in the copepod Eucalanus californicus Johnson. J Geophys Res 96: 14849-14858

Tande KS, Hopkins CCE (1981) Ecological investigations of the zooplankton community of Balsfjorden, northern Norway: the genital system in Calanus finmarchicus and the role of gonad development in overwintering strategy. Mar Biol 63:159-164

Tester PA, Turner JT (1990) How long does it take copepods to make eggs? J exp Mar Biol Ecol 14:169-182

Thompson AM, Durbin EG, Durbin AG (1994) Seasonal changes in maximum ingestion rate of Acartia tonsa in Narragansett Bay, Rhode Island, USA. Mar Ecol Prog Ser 108:91-105

Tourangeau S, Runge JA (1991) Reproduction of Calanus glacialis under ice in spring in southeastern Hudson Bay, Canada. Mar Biol 108:227-233

Turner JT (1984) The feeding ecology of some zooplankters that are important prey items of larval fish. NOAA Tech Rep NMFS 7

Uye SI (1981) Fecundity studies of neritic calanoid copepods Acartia clausi Giesbrecht and A.steueri Smirnov: a simple empirical model of daily egg production. J Exp Mar Biol Ecol 50:255-271

Uye SI, Shibuno N (1992) Reproductive biology of the planktonic copepod Paracalanus sp. in the Inland Sea of Japan. J Plankton Res 14:343-358

Uye SI, Iwai Y, Kasahara S (1982) Reproductive biology of Pseudodiaptomus marinus (Copepoda: Calanoida) in the Inland Sea of Japan. Bull Plankton Soc Jpn 29:25-35

Verity P, Smetacek V (1996) Organism life cycles, predation, and the structure of marine ecosystems. Mar Ecol Prog Ser 130:277-293

Ward P, Shreeve RS (1995) Egg production in three species of Antarctic calanoid copepods during an austral summer. Deep-Sea Res Part I 42:721-735

Webber MK, Roff JC (1995) Annual biomass and production of the oceanic copeopd community off Discovery Bay, Jamaica. Mar Biol 123:481-495

Zar JH (1999) Biostatistical analysis, 4th edn. Prentice-Hall International, Englewood Cliffs, NJ

Submitted: June 5, 2000; Accepted: January 3, 2001

Proofs received from author(s): November 14, 2001 